\title{
$\begin{array}{ll}\text { Research Square } & \text { Preprints are preliminary reports that have not undergone peer review. } \\ \text { They should not be considered conclusive, used to inform clinical practice, }\end{array}$ or referenced by the media as validated information. \\ Criteria prioritization for sustainable development of second-generation bioethanol in Thailand with an application of Delphi-AHP technique
}

Piradee Jusakulvijit ( $\nabla$ piradee.jusakulvijit@ufz.de)

Helmholtz-Zentrum fur Umweltforschung UFZ https://orcid.org/0000-0001-9702-9448

Alberto Bezama

Helmholtz-Centre for Environmental Research - UFZ: Helmholtz-Zentrum fur Umweltforschung UFZ

Daniela Thrän

Helmholtz centre for environmental research - UFZ

Original article

Keywords: Second-generation bioethanol, stakeholder's perception, Delphi-AHP technique, participatory criteria prioritization

Posted Date: December 28th, 2020

DOl: https://doi.org/10.21203/rs.3.rs-135251/v1

License: (c) (1) This work is licensed under a Creative Commons Attribution 4.0 International License.

Read Full License 


\section{Criteria prioritization for sustainable development of second-generation bioethanol in Thailand with an}

\section{2 application of Delphi-AHP technique}

3

4 Piradee Jusakulvijitit, ${ }^{1,2}$ Alberto Bezama ${ }^{1}$, Daniela Thrän ${ }^{1,2,3}$

$5{ }^{1}$ Helmholtz Centre for Environmental Research - UFZ. Department of Bioenergy. Permoserstr. 15, 04318 Leipzig, Germany

62 University of Leipzig, Germany. Faculty of Economics and Management Science. Augustusplatz 10, 04109 Leipzig, Germany

$7 \quad 3$ Deutsches Biomasseforschungszentrum gGmbH - DBFZ. Torgauerstr. 116, 04347 Leipzig, Germany

\section{Abstract}

Background:

The availability of underexploited agricultural residues in Thailand opens up the opportunity to supply second-generation

bioethanol production. The national implementation of residues-to-biofuel can potentially initiate the bioeconomy and greenhouse gas mitigation, requiring engagement from the multi-stakeholders to develop effective policy recommendations. Thus, the study aims to optimize the implementation of the national strategy from a multi-criteria approach to evaluate the concerned aspects and important indicators for second-generation bioethanol development through a participatory prioritization by the actual stakeholders

Methods:

To analyze the relevance of the different dimensions regarding important levels of criteria, a Delphi-AHP technique was applied. The evaluation process was conducted with different stakeholders and elaborated by using a pairwise comparison of 4 dimensions (main-criteria) and 12 indicators (sub-criteria). The evaluation was applied to the participants to share their preferences evaluating the most important factors from the aspect of technical feasibility, environmental impacts, economic feasibility and social impacts.

Results:

Bioethanol stakeholders in Thailand from 5 different branches (industry/ business sectors, NPO/NGO, governmental sectors, academic/research institute and financial institution/bank) participated in the Delphi survey. The 20 expert's evaluation of four dimensions reveals the highest score from the economic feasibility (32.3\%), followed by environmental impacts (25.6\%), technical feasibility (24.0\%) and social impacts (18.1\%). From the sub-criteria assessment, the participants selected 'final price per liter', 'added value of input materials' and 'net energy balance' for the top three important indicators among 12 sub-criteria. 
1 process of employing different associated backgrounds into account at the step of policy planning in addition to the

2 consideration of affiliations.

3 Conclusions:

4 The stakeholder's participatory evaluation indicated the importance of economic aspects, highlighting the necessity of the

5 governmental driven policy that needs to be considered. However, implementation scenarios have to be embedded in a

6 broader range of aspects because all the dimension were rated with high impacts. For the future sustainable bioenergy, involvement from stakeholders' opinions can imply multifaceted scenarios that may interconnect to the social acceptance and 8 benefits for all relevant players when considering the development of advanced bioenergy as a policy recommendation.

\section{Keywords}

11 Second-generation bioethanol, stakeholder's perception, Delphi-AHP technique, participatory criteria prioritization 12 
The greenhouse gas (GHG) reduction goal is an urgent driver for Thailand to search for sustainable energy sources to pursue effective mitigation. Thailand has committed to the Paris Agreement at the COP21 meeting to reduce 20-25\% GHG intensity from the business as usual by $2030[1,2]$. Constantly increasing energy demand leads to the requirement of a sustainable energy transition to stay within the greenhouse gas emission budget. Taking an opportunity from agricultural products in the country, Thailand attempts to substitute the consumption of fossil fuels with bioenergy production from the agricultural crops. At present, bioenergy production in Thailand comprises bioethanol and biodiesel. In particular, for bioethanol production, cassavas and sugarcanes are cultivated to serve the biofuel supply in the transportation sector. According to the long-term promotion of bioethanol, supported by the Alternative Energy Development Plan (AEDP 2015), the production goal in 2036 is aimed to be 4,136 million liters [3], increasing from production in 2019 by $157 \%$ [4].

This conventional bioethanol development thus far benefits on the abatement of dependency on fossil fuel. However, there are challenges that need to pay attention to while biofuel production becomes intensified in proportions. The controversial issues involve the production process, as the projected goal of ethanol production could associate with higher requirement of crops cultivation. Due to a limit of yield per area up until now, the national policy to promote bioethanol for substitution of fossil fuel is projected for a land use expansion [5-7], which also affects land use of food and other crops cultivation [6]. In this sense, the conflict between the crops supply and increasing bioethanol demand needs to be taken into consideration to achieve a sustainable long-term bioethanol policy in Thailand.

Nowadays, sustainability for future bioenergy development has been scrutinized extensively. Although the conventional production of biofuel has admittedly provided the benefits of fossil fuel replacement, the widespread commercialization of the biofuel industry from the past decades has been inevitably associated with the environmental side-effects, involving conflicts of land use for food-based crops cultivation [8-10]. The recent researchers and stakeholders have paid more attention to pursue the transition of bio-based products or bioenergy systems towards sustainable direction by addressing indicators from holistic points of view based on United Nations Sustainable Development Goals (SDGs) [11-13]. The exemplary framework can be observed from the policy by European Union (EU), which has shown more concerns on sustainability and environmental harmonization for biofuels and bioliquids implementation [8].

Towards the direction of sustainability, one of the implementable concepts is the utilization of the regional biomass, such as wood-based wastes, to supplying as bio-materials [14-16]. The strategy would not only provide the environmental and economic advantages, but the investment in bio-based industries is also expected to contribute to social benefits, such as increasing workforce from the local business, educational opportunities, and research projects for enhancing innovation [12, $17,18]$.

Under the debate of sustainable resource use, the energy sector is considered as one of the potential cascading use of agricultural residues to enhance values of agricultural industries in the form of bioenergy [19]. Particularly, the bioenergy from 
lignocellulosic biomass showed the advantages in fostering the utilization of agricultural wastes, saving land use along with socio-economic benefits, such as food security [20]. In Thailand, there are agricultural residues generating and being left unused in the farm areas distributed across the country. The regional availability of biomass provides an opportunity for Thailand to make use in the production of higher-value products. The agricultural residues have been found to have an excessive amount from the plantation of the major crops, such as rice, sugarcanes, cassavas, and palms [21]. Nonetheless, the practical applications of agricultural residues are limited to only the primary utilization, such as animal feed, fertilizer, and raw material for electric power plants [22-25].

Behind this background, the dimensions for a successful implementation of second-generation bioethanol in Thailand are anticipated to be manifold. Apart from the biofuel as energy supply, which can support the concept of controlling land use expansion, the utilization of leftover lignocellulosic materials could be projected to mitigate the environmental impacts from the open field burning issue $[26,27]$. In addition to that, the utilization of agricultural residues would provide the possibility of longer value chains of biorefinery production, which also plays an essential role in bioeconomy concept [28, 29], generating direct and indirect socio-economic benefits [12, 30, 31].

Although the conversion of lignocellulosic biomass to bioethanol has been developed to the pilot level [28], it can be stated that the concept of utilizing agricultural residues for biofuel purposes has never been proposed to the stakeholders or put into consideration at the policy making level. In order to promote the commercialization of second-generation ethanol for the sustainable bioenergy framework, the important elements would involve decision-making based on different backgrounds and complexity of stakeholders. It is nearly impossible to solely take the factor of technological feasibility into account, as the production chain consists of several industrial and service branches such as agricultural, logistics, and at times many production facilities [32].

In the process of energy planning, aside from techno-economic feasibility, the estimation of social and environmental impacts has become a vital concern to evaluate for the most sustainable system [33]. The system optimization from an environmental perspective is necessary to be accounted; however, it may in turn cause the conflict with technical or economic development $[34,35]$. Therefore, instead of approaching with only single dimension, which may lead the decision-making to be coupled with risks, conflicts, and tradeoffs [36], the impact of multi-dimensional attributes are necessary to be evaluated and selected from the actual awareness and concerns from stakeholder's perception.

Even though numerous studies have conducted multi-criteria decision analysis (MCDA) in the field of bioenergy assessment up until the present [35], the evaluation by eliciting the stakeholders' opinions through the participatory assessment under the topic of second-generation bioethanol production in Thailand's context has not been executed. Inducing expert perspectives into system evaluation for the advanced bioethanol production is considered newness from the study. 
The promotion of bioethanol development in Thailand contributed the benefits to the transport section since it provided the self-sufficient sources of energy supply. Since 2004, commercialized bioethanol shows a constant growth according to fostering policy for production and consumption sides. Nonetheless, the bioethanol development plan and policy of Thailand, namely the Alternative Energy Development Plan (AEDP, 2015-2036), has barely integrated the socio-economic dimension since it involves crossing-disciplinary fields and authority from governmental organizations. On the contrary of achievement in replacing the fossil fuel, the long-term policy is prone to encounter with constraints occurred due to several aspects, which may become the bottlenecks for the bioethanol development policy in Thailand in the future.

According to the study by Chanthawong et al., the multi-criteria evaluation conducted by relevant stakeholders in the biofuel market revealed their perceptions of the current bioethanol policy implication [37]. Although the participants agreed that Thailand's bioethanol policy advocates energy security in the country, the biofuel promoting approach still lacks the concrete strategy to improve the crops cultivating management for the long-term development goal. Due to the limited farm areas, there is a bottleneck to stabilize the sources for biofuel supply to correspond to the production goal in the future. Along with that, prices of raw material, as well as the production cost are considered significant influences. Since biofuel production mainly varies on the crop price, the fluctuation of the feedstocks price is a worrying issue that the government needs to overcome.

From the background of instability in raw materials price, the biofuel pricing mechanism in Thailand is structured by a subsidization system [38]. The stakeholders of bioethanol business projected the opportunity that demand can still grow steadily, as long as there are incentives for driving the demand in terms of blending mandatory, tax reduction or subsidization [37]. The subsidy is collected from the non-bio-based fuel as oil funds. The oil funds are the instrument to stabilize the retail price of bioethanol blended gasoline, which also encourages the consumption of biofuel by maintaining the discount for users of bioethanol blended gasoline type, E20 and E85 (20\% and 85\% ethanol blending rates, respectively) [38]. Nonetheless, the reliance on governmental subsidization has also been criticized as a cause of distortion of the actual price and a possible long term negative effect to the market [39]. By controlling retail price for consumers, the lower price of gasoline is related to entail the energy consumption to become higher [39, 40].

Apart from the issue concerning market mechanism of biofuel, it has been unclear from the policy making regarding the sustainable strategy of bioethanol development. In the study by Lecksiwilai et al., the lack of attention on environmental impacts from the currently imposed policy was emphasized as an urgent topic that needs to be accounted [41], especially the dimension of land use change corresponding to the increasing of agricultural production [6]. The fact that crop yields of sugarcanes and cassavas have not improved significantly in the last decades [42, 43], the tendency of future scenarios is likely to induce the increasing land use for crops cultivation in order to reach the target of ethanol production goal [6, 44]. While the land use change for expanding cultivation areas have to deal with $\mathrm{CO}_{2}$ extracted from soil carbon stock $[6,45]$, enhancement of crop yields, which was contemplated as one of possible solutions under the land use restriction, possibly demands higher input 
fertilizers and pesticides. Consequently, the foreseen limited crops yields would decrease the GHG mitigation effect of the biofuel, resulting in environmental tradeoffs from the life cycle GHG emission $[6,41]$. In addition to that, the cultivation of cassavas and sugarcanes is associated with intensive water footprint per ton of crop production. It has been investigated that the water footprint in the cassava plantation required double amount of water comparing to sugarcane plantation [46].

The complications of current policy also involve a socio-economic aspect. Concerning the traditional practice of sugarcane plantation, the agricultural residues management is executed by field burning [47, 48]. At the end of each cultivating season and before starting the new cultivating round, the preparation steps comprises the sugarcane trash burning. This procedure gives impact to not only the environmental burden, but the health issues of the farm workers also are directly affected, giving disadvantages to the farmers [49]. In particular for the agricultural laboring system, unguaranteed crop prices for stable incomes of the farmers, and unequally protected by national labor law affect the quality of farming job. Thus, several dimensions take part in the bioethanol policy, which are necessary to be evaluated for the long term sustainable development [50].

The information from the mentioned studies reflected the existing issues and prospective barriers in the bioethanol policy in Thailand particularly on the feedstocks supply. Exploring a substitution of the conventional feedstocks is recognized as a promising option especially from the available agricultural residues. The utilization of lignocellulosic biomass for secondgeneration bioethanol have verified the reducing effect of GHG emissions based on ethanol conversion potential [27, 51]. The residues derived from crop plantation showed optimistic future in terms of availability, non-food materials and promising results of GHG reduction [52]. Nonetheless, the assessment from the studies thus far still affirmed that production cost was the imperative constraint that still needs to be tackled for the development to the commercial-scale of advanced biofuel [53-55].

From the angle of current biofuel policy, there are many underlying opportunities for the bioethanol development to reach the long-term goal. Towards the process of policy planning for advanced bioethanol development, aside from technical and economic viability, the estimation of social and environmental impacts have become vital concerns to evaluate for the most sustainable system [33]. It is irrefutable to say that to commercialize the advanced biofuel technology, it involves many uncertainties, trans-disciplines, standards and measures as well as the related players, such as the crops growers, private firms, governments and ending products users $[35,56,57]$. Therefore, the proposal of the alternative system of bioethanol should be aware comprehensively from various backgrounds and based on the bottom-up opinions sharing by incorporating multidisciplinary organizations in the bioethanol value-chain.

\section{Objective of the study}

Considering that drawbacks and projected constraints from the current first-generation bioethanol would inevitably occur in the near future, transitioning from the conventional ethanol production to the second-generation technology is a promising solution. For a future sustainable policy, it is necessary to construct the system based on the assessment from the multi- 
disciplinary aspects. In order to bridge the gap in the transdisciplinary assessment in regard to sustainable framework for policy implications, socio-economic and environmental variables require to take part in the system analysis and decision-making.

Thus, the objective of this study is to evaluate the level of importance of criteria from several relevant dimensions by involving the stakeholders' perspectives. The outcomes of criteria prioritization are expected to reflect the most concerned topics and preferences that bioethanol stakeholders encountered at the current stage, which could be beneficial for secondgeneration bioethanol policy recommendations. The results of criteria prioritization by the stakeholders in this study are planned to be accommodated in the scenarios analysis as a further study step to determine the consensual sustainable strategy for secondgeneration bioethanol development.

Consolidating the different viewpoints from the various branches of stakeholders with the application of Delphi-AHP (Analytic Hierarchy Process) in the context of second-generation biofuel policy in Thailand is considered a novelty. With this approach, the stakeholders are provided the opportunity to share their preferences and concerns which could become a foundation for the second-generation ethanol policy development. In addition, the stakeholders are given chances to rethink the preferences under the consideration of the first survey round. Following the Delphi-AHP procedures, it is expected to enable the policymakers to objectively achieve the efficient and justified indicators in the policy design, since the technique could eliminate the subjective opinions, which might lead to the bias decisions.

\section{Methods: Integrated approach of Delphi-AHP}

AHP, a multi-attribute decision-making method, was initially developed by Saaty, being used broadly in the policy-making process [58]. The application of AHP was verified to be a functional tool for dealing with various indicators and the selection of alternative scenarios for strategic planning [59]. It is categorized as a type of value measurement model that helps decisionmakers prioritize their preferences from the alternatives and criteria set through the scoring system by comparing pairwisely and giving the weights for levels of importance or preference [58]. This method results in the relative weights of each particular criterion that shares the same goal of the study [60].

However, the practical tools of MCDA can also be combined from multiple types to provide dimensions of the study, rather than limited to only one [61]. To achieve a collective decision for policy-making from the stakeholders' perspectives, the current study applied the Delphi technique in the survey conduction. Delphi survey is a useful tool that has been developed for a wide range of areas, for instance, Delphi for upcoming technologies [62, 63], Delphi for policy-making [64], or Delphi for problem-solving [65]. The characteristics of this technique showed the advantage for encouraging the anonymity during the survey conduction without physical assembly. In spite of that, the fundamental feature for the process being used in this study is the transparency of the answers among the participants and the repetition of survey round based on the disclosure to seek the consensus point [66]. 
In this study, Delphi-AHP methods were deployed to prioritize the important aspects and criteria regarding commercialization and policy implications of the second-generation bioethanol in Thailand. The evaluation of important levels of the associated criteria was conducted by the relevant experts. The criteria were addressed from crossing dimensions of a whole supply chain from farm to ethanol production, including technical, environmental, and socio-economic aspects from diverse participants' perspectives.

The process flow of the survey and data analysis is summarized in Figure 1.

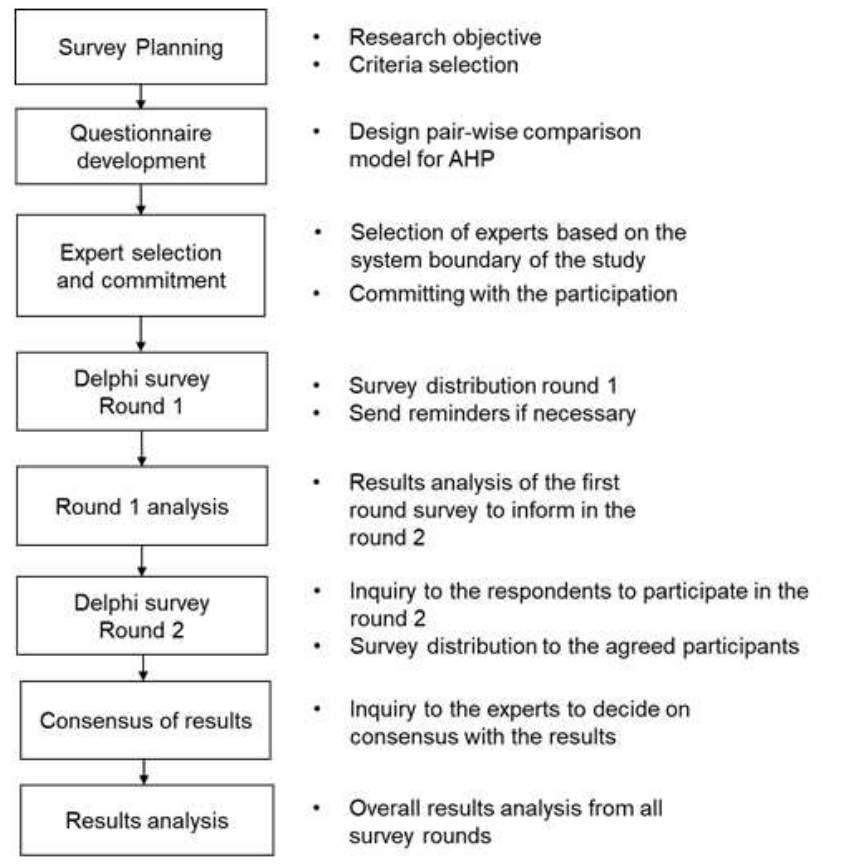

Figure 1 process flow of the current study

\section{Survey planning}

The research question was planned to pursue the objective of the study. The questionnaire was planned to inquire the experts' opinions to vote for the preferable criteria to be considered in the second-generation ethanol development in Thailand.

14 For the initial step, the aspects and criteria set were selected and categorized separately in technical, economic, environmental, and social aspects of assessment by sorting from the literature studies and then were designed to pursue the research objective (see Objective of the study).

\section{Design of the questionnaire}

Following that, the format of questionnaire was designed to let the respondents rate the important level by pairwisely 
distributed questionnaire can be referred to in Supplementary material 1. The exemplary questionnaires of criteria comparison are presented in section of the supplementary information. (Supplementary information)

\section{Expert panel design}

The principle of Delphi-survey for collecting opinions shall be taken place with diverse backgrounds of experts group under the specific topic. Based on that, the selection of panel of participating experts was considered from experiences in the field of bioethanol production and other topics in line with the bioethanol supply chain corresponding to the system boundary of assessment in this study, covering biomass feedstock providers, ethanol producers and energy corporations as bioethanol purchasers. Principally, each specialist does not acknowledge each other in order to avoid interference between respondents.

Aiming to structure the panelists from the diverse points of views to obtain the outcomes from different opinions and concerns, the experts were selected from 5 distinctive functionality of organizations, which are 1) governmental sectors, 2) business sectors, 3) non-profit or non-governmental organizations, 4) academic or research institutes and 5) financial institutions and banks. In this study, the systematic selection of the participants was carried out from each background to represent the function of organization as well as the opinions towards bioethanol production in Thailand.

In a realistic practice, it is not possible to personally indicate the evaluator in every organization due to the fact that some organizations have the delegation system to allocate the tasks, especially in large-sized enterprises. The delegated experts were internally assigned to deliver the Delphi-survey, meaning that the evaluator was determined to be adequate for representing evaluation in the survey conduction under the justification of the organizational executive level. Nonetheless, it was possible to directly contact the participants in person in some cases, such as the experts in the academic fields.

\section{Delphi survey rounds and consensus}

In the first round, the Delphi survey questionnaires were distributed to potential targets. After gathering all evaluated scores from the participants, AHP was applied to weight the criteria for prioritizing the level of importance. The hierarchical structure of the variables in this study was determined based on the calculation procedures, as mentioned in section Analysis of the survey data from AHP method. In the following step, the results from round one of Delphi-AHP were distributed to the participants. The preliminary compilation of results was informed to the experts to provide the opportunity to participate in the second-round survey. After each round of the survey, the participants were asked to consent to the results or re-evaluate the survey. Considering a principle of Delphi survey, the summary of results from round one would encourage the experts to revise the outcomes of their judgements from the earlier survey round [67]. 
The criteria in this study were selected from the publications related to the field of energy analysis, as summarized in Table

1. The goal is to prioritize the preferable criteria to be focused on the context of second-generation bioethanol. The derived scores of criteria ranking are planned to be undertaken as parameters in the system analysis for proposing the second-generation bioethanol as a policy recommendation.

The criteria were selected based on the fundamental that they are independent of one another but eventually correspond to the goal of the study. The scores of criteria evaluations are subjected to contribute in the scenarios study as the further step of the research. The set of criteria relatively affects the results of multi-criteria decision-making outcomes. To achieve the goal in this study, the set of criteria was constituted from technical, environmental, economic, and social aspects. The variables introduced in this study refer to the scope cradle-to-gate, ranging from farm areas to ethanol production as a boundary in this study.

The selection of required criteria in this study shares the common ground that they are the quantitative factors, which can be processed in the MCDA. Criteria to be studied were categorized by 4 main aspects of main criteria, comprising 3 sub-criteria under respective aspects, providing a total of 12 sub-criteria to be evaluated. A simple scheme of the hierarchical structure is shown in Figure 2.

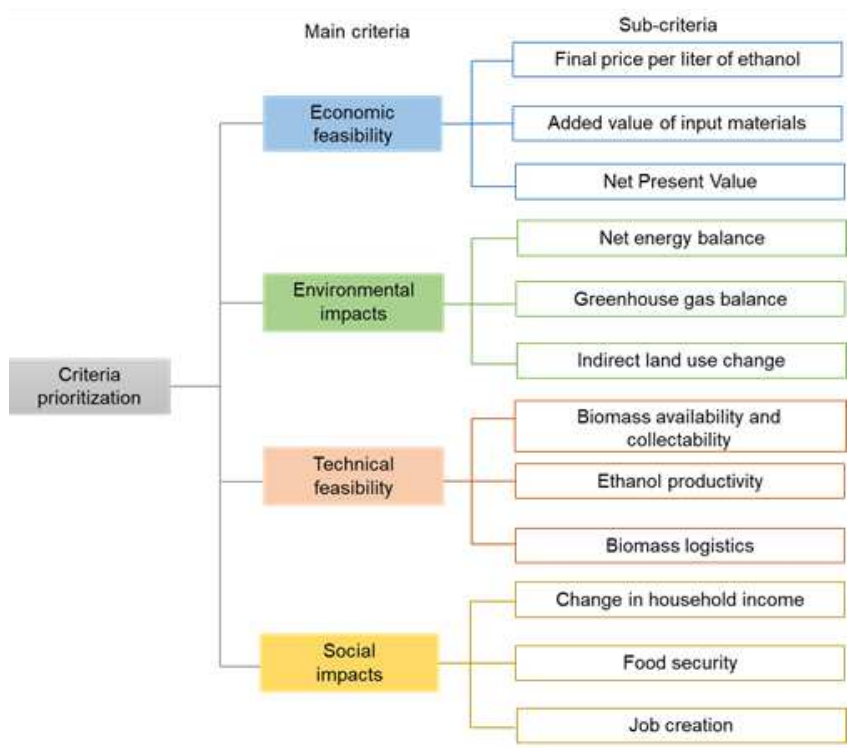

Figure 2 Hierarchical structure of selected main criteria and sub-criteria

$\underline{\text { Technical feasibility }}$

Second-generation bioethanol has been improved for its technical potential as commercialized production has developed in these decades [28]. Nevertheless, the potential of this advanced technology in the context of Thailand has to be verified. 
in production units. Moreover, the availability of input materials indicates the potential location for installing facilities and determines the production capacities [68, 69].

Next, to verify the potential of input material, ethanol conversion efficiency from the available feedstock needs to be taken into consideration. The ethanol productivity from lignocellulosic materials plays a major part in evaluating cost-benefits [70] since the ethanol conversion efficiency can be deficient due to the constraint from the complex structures of lignocellulosic components [71]. Therefore, conversion process requires more operating cost and input energy compared to the conventional production [53].

In regard to the related elements in the production boundary, biomass logistics is one of the key factors for assessing technical feasibility. This factor refers to distances and transferable amounts of biomass from supply area to the ethanol production process and the end-use stations. Logistics work involves the terms of harvesting, collecting, baling, and handling process [71]. The logistics system interconnects between the sources of feedstocks and the bioenergy industry, directly connected to the size of production units, plant location, transportation system [72, 73]. Other than the feedstocks to energy conversion that influences the production cost, logistics management can enable the optimization of the plants scale, implying the location based on the optimal distance of the supply site, which can enhance the cost minimization [74, 75].

\section{Economic feasibility}

Three indicators applied in the evaluation in this study comprise 'Net present value (NPV)', 'Final price per liter', and 'Added value of input materials'. In terms of business feasibility, NPV indicates the profitability from future cash flows during the investment lifetime after discounted to the present value, which is a parameter to analyze the attractiveness of a project investment [76, 77]. An estimated price of ethanol, including all costs in the supply chain, is also imperative to determine the project's feasibility. NPV can be calculated from the expenses generated from all elements in the production chain, such as the capital cost from equipment installation, and the operational cost from biomass management and production [76].

The final selling price could be referred as the structure of minimum ethanol selling price. Principally, the final price of biofuel is constructed from costs of raw material and production process under the condition of $10 \%$ internal rate of return (IRR). The production cost of bioethanol from lignocellulosic feedstocks comprises the capital costs of the production plants and the operational cost. In spite of the cost of cellulosic raw materials that is lower than from the conventional sugar- or starchbased biomass $[78,79]$, the competitiveness in terms of economic viability, comparing to the first-generation, it has always been inferior for the second-generation bioethanol, especially due to the cost of conversion process, including cellulase enzyme and microbes for fermentation $[30,80]$. Nonetheless, for the bioethanol retail price in Thailand, there are several elements which stimulate the growth of bioethanol in the market, for instance tax exemption or subsidization [38]. Currently, in Thailand, the price of ethanol has not been regulated by the government but rather determined by the actual ethanol trading price between ethanol manufacturers and oil traders [81]. 
In addition to the economic analysis from the production process, the possibility to extend the added values of input materials is also a vital factor to consider. Conversion of biofuel from the residues has high potential in the value addition, varying on the types of input materials and the output products. The value addition of the biomass from conventional production can increase through the technological development $[82,83]$. Compared with the biofuel productions from crop farming, utilizing lignocellulosic biomass as input materials for higher value-added was assessed to give more economic benefits and socio-economic advantages such as expanding the employment rates [84]. In recent years, industrialized ethanol production from lignocellulosic biomass has transformed from only ethanol production to value-added co-products. For example, from fermentation process of the residual by-products, it is possible to derive lignin plastic composite material simultaneously as biorefinery productions [85].

\section{$\underline{\text { Social impacts }}$}

The social benefits and drawbacks for the locals should be concerned when the project of production plants is implemented, referring to influential indicators for policy implications [86]. The criteria under this topic are selected based on social impacts, including 'Job creation', 'Food security', and 'Change in household income'. As it has been investigated by Brinkman et al., macroeconomic impacts such as income and employment rates are often used in the field of bioenergy [87].

Job creation can relate to several spectra of indications, such as an employment rate, income generated, and the ratio of skilled/unskilled laborers [87]. Commonly, job creation is the key indicator being used in the socio-economic assessment [31, 59, 88], which is undertaken as a bottom-up analysis method by demonstrating from the production process [87]. The model of decentralized production plants is especially an attractive scenario to create higher employment rates as beneficial for regional development [59]. Factors regarding job creation and added values are also important for evaluating the bioeconomy since the enhancement of the bioeconomy potentially increase the value-added per person due to the improvement of labor productivity [84].

In the case that the production of food crops is associated with non-food purpose business, it is necessary to take the factor of food security into account. The increase of biofuel demand has led to the rising price of maize, which affected the contribution of grains production in the food industry became smaller due to the expansion of land use [89]. The parameters related to food security imply the sufficiency of food for the inhabitants regarding physical, social, and economic possibilities. The indicators are associated with, for example, the sufficiency of food availability, changes in areas of food crops, food accessibility, reasonable price, and sufficient calorie intake $[89,90]$. Nonetheless, utilizing agricultural residues is prospected to lessen the conflicts on food price competition from land use with conventional counterparts [91].

Another engaging variable in the study of the socio-economic aspect is the indicator of household income. This indicator is used in monitoring economic growth as part of sustainable bioeconomy development [15]. Household income can be used to indicate equality by evaluating the income distribution subjected to the rural and urban areas as a diversity of income exists, 
particularly in the developing countries [92]. In conventional bioenergy, the agriculture-oriented households are influenced to shift to producing energy crops by the biofuel policy and prospective household income [93]. On the contrary, for the advanced bioenergy projects, the expectable incomes rely significantly on the required jobs in the facility construction, plant operation, and the capacity of the plant [94]. Moreover, the process of collecting agricultural residues would be a favorable incentive for the local crop producers, as it might provide additional income in addition to crop cultivation [95].

\section{$\underline{\text { Environmental impacts }}$}

Biofuel promotion is an effective tool for the substitution of fossil fuel. However, an extensive production and consumption have induced several adverse effects, including expanding land use and GHG emission [44, 96]. With a goal to optimize the bioenergy to achieve sustainability in development, environmental indicators are compiled to be prioritized in the study. Three parameters, namely 'Indirect land use change (iLUC)', 'Net energy balance' and 'Greenhouse gas (GHG) balance', are selected for the survey interview.

The iLUC indicator has been widely applied in the evaluation of biofuels since it is an indicator that directly indicates the consequence of alternating previous activity in the cropland into bioenergy targeted production. This indicator has been remarked as more complicated than direct land use due to its definition since the evaluating method includes the outside areas of the monitored biomass production [97]. In the case of the cultivation land in Thailand, the land use for bioenergy production mainly expands from the displacement of other existing crop cultivation. Risks of iLUC have been investigated from the current bioethanol production from cassava and sugarcane comparing to fossil fuel. The study revealed that GHG emissions per liter from conventional feedstocks occupied around 40-80\% of that from fossil fuel after including the iLUC [98].

In terms of energy analysis, net energy balance is a parameter for assessing environmental impacts, indicating how the efficiency of the bioenergy production process is. Accordingly, it can be applied with a life cycle assessment to evaluate $\mathrm{CO}_{2}$ balance [99]. This indicator defines a comparison between required input energy and achievable ethanol to measure the positive or negative outcome, considering the process of converting raw materials into ethanol, which varies heavily on the type of primary energy consumption. Along with the flow of energy input-output, the process involves not only directly with $\mathrm{CO}_{2}$ emission but also with cost factors, which can determine the feasibility of the project [100].

Net energy yield has also been analyzed in terms of gross energy yield per area as evaluated by Vries et al. The assessment helps select adequate bioenergy production resources, which gives the highest net energy yield [101]. However, the value is not limited to energy per area, but it also involves required energy factors during the production process, such as farm machinery, fertilizing system and product transportation [100, 101]. Referring to the investigation by Mishra et al., bioethanol production from wheat straw resulted in net energy ratio (NER) $>1$. Nonetheless, the study remarked that the NER would be offset depending on the types of consuming energy in the process. 
The GHG balance refers to the GHG reduction comparing to the emission throughout the production phases, which relies on various factors, such as types of fossil fuel and fertilizers in crops plantation [102]. GHG balance has been attracted to researchers in the study of conventional bioenergy since it showed the negative balance (input > output) from energy crops cultivation and the soil carbon sequestration [103]. In addition to the $\mathrm{GHG}$ emission from land use change, the life cycle $\mathrm{CO}_{2}$ from farm to end-products is the factor to compare $\mathrm{CO}_{2}$ mitigation with the conventional biofuel production and fossil fuel [104], since types of fuel as an input energy influence the total GHG balance. Meanwhile, it is possible to save output GHGs with the generated co-products in the biofuel production system [105].

Table 1 Sets of indicators for the purpose of bioenergy evaluating application

\begin{tabular}{|c|c|c|c|}
\hline $\begin{array}{l}\text { Main criteria } \\
\text { (Aspects) }\end{array}$ & Sub-Criteria & Units & References \\
\hline \multirow[t]{3}{*}{$\begin{array}{l}\text { Technical } \\
\text { feasibility }\end{array}$} & $\begin{array}{l}\text { Biomass availability and } \\
\text { collectability }\end{array}$ & $\mathrm{Kg} \mathrm{ha}^{-1} \mathrm{y}^{-1}$ & {$[68,69,106]$} \\
\hline & Ethanol productivity & Liters $\mathrm{kg}^{-1}$ & {$[107,108]$} \\
\hline & Biomass logistics & Ton day ${ }^{-1}, \mathrm{~km}^{2}$ day $^{-1}$ & {$[73-75]$} \\
\hline \multirow{3}{*}{$\begin{array}{l}\text { Economic } \\
\text { feasibility }\end{array}$} & Net present value & US\$ & {$[76,109,100]$} \\
\hline & Final price per liter & US\$ Liter ${ }^{-1}$ & {$[110,111]$} \\
\hline & $\begin{array}{l}\text { Added value of input } \\
\text { materials }\end{array}$ & US\$ ton ${ }^{-1} y^{-1}$ & {$[82,112,113]$} \\
\hline \multirow[t]{5}{*}{ Social impacts } & Job creation & Persons $\mathrm{y}^{-1}$ & {$[31,86,114]$} \\
\hline & Food security & US\$ tons crops $^{-1}$ & {$[90,115,116]$} \\
\hline & & Tons ha ${ }^{-1}$ or Kcal capita ${ }^{-1}$ & \\
\hline & Change in household income & US $\$ \mathrm{y}^{-1}$ or & {$[92,103,117]$} \\
\hline & & US\$ household ${ }^{-1} \mathrm{y}^{-1}$ & \\
\hline \multirow[t]{4}{*}{ Environmental } & Indirect land use change & (Biomass growing capacity) $\mathrm{ha}^{-1} \mathrm{y}^{-1}$ & {$[98,118]$} \\
\hline & & or $\mathrm{kg} \mathrm{CO}_{2 \text {-eq }}(\text { Biomass growing capacity })^{-1}$ & \\
\hline & Net energy balance & $\mathrm{GJ} \mathrm{ha}^{-1} \mathrm{y}^{-1}$ & {$[101,119,120]$} \\
\hline & GHG balance & Tons $\mathrm{CO}_{2}$ equiv. year & {$[102,104,121]$} \\
\hline
\end{tabular}

After retrieving quantitative and qualitative opinions from the participatory Delphi survey conduction in this study, AHP is applied to interpret the subjective opinions and systematically transform them into objective information. AHP is a tool that helps make decisions from complex sets of alternatives to reach the goal of multi-attributes decision-making [122]. The 
Table 2 Scales of importance for using in pairwise comparison pairwise comparisons [58].
13

complexity from a variety of quantitative data is able to be reduced and become one-dimensional figures. According to Saaty, the AHP method is mainly performed by two steps comprising the hierarchical structure and rating the scales on elements in

The criteria were reviewed via pairwise comparisons using the provided rating scores, as the intensity of importance and definition are shown in Table 2. Since the format of criteria weighting was designed for the participants to rate by selecting a level of intensity from multiple choices (Supplementary information), in order to process the data according to AHP, it is necessary to convert the reviewed criteria and intensities into the matrix form. If the respondents vote for the left column criteria, the scales of 1-9 shall be filled out in the matrix for specifying that the row was more important than criteria from the column. In the reverse case, if the variables were located towards the right side, then criteria on the row were intended to be less important. Thus, the reciprocal numbers; $1 / 3,1 / 5,1 / 7,1 / 9$, or 1/2, 1/4, 1/6, 1/8 have to be placed for restructuring.

\begin{tabular}{|c|c|c|}
\hline Intensity of importance & Definition & Explanation \\
\hline 1 & Equal importance & Two activities contribute equally to objective \\
\hline 3 & Moderate importance of one over another & Experience and judgment favor activity over another \\
\hline 5 & Essential or strong importance & $\begin{array}{l}\text { Experience and judgment strongly favor one activity over } \\
\text { another }\end{array}$ \\
\hline 7 & Very strong importance & $\begin{array}{l}\text { An activity is strongly favored and its dominance } \\
\text { demonstrated practice }\end{array}$ \\
\hline 9 & Extreme importance & $\begin{array}{l}\text { The evidence favoring one activity over another is of the } \\
\text { highest possible order of affirmation }\end{array}$ \\
\hline $2,4,6,8$ & $\begin{array}{l}\text { Intermediate values between the two adjacent } \\
\text { judgments }\end{array}$ & The scores using when compromise is needed \\
\hline
\end{tabular}

The matrix $\mathrm{A}$ is structured from $n \times n$ criteria as presented in the equation 1 .

$$
\mathrm{A}=\left[\begin{array}{cccc}
1 & a_{12} & \ldots & a_{1 n} \\
a_{21} & 1 & \ldots & a_{2 n} \\
\vdots & \vdots & \ddots & \vdots \\
a_{n 1} & a_{n 2} & \ldots & 1
\end{array}\right]
$$

Then, matrix A is converted into normalized matrix in order to calculate the relative weights from the same level of criteria that reflect the preference scores as input by the experts. The matrix $\bar{A}$ is a normalized pairwise matrix of matrix A, resulting from dividing each value in the same column by summation of factors in the respective column. The step of normalization is the calculation for the results of relative weights, where all the elements are a sum of 1 . The derived values of each element 
6 Where $\bar{W}$ refers to the weighted sum vector as quantified from eigenvector calculation. Meanwhile, $\lambda_{\max }$ is the maximum 7

Table 3 Scales of random index as experimented by Saaty [58].

\begin{tabular}{ccccccccccc}
\hline Matrix size (N) & 1 & 2 & 3 & 4 & 4 & 6 & 7 & 8 & 9 & 10 \\
\hline $\begin{array}{c}\text { Random Index } \\
\text { (R.I.) }\end{array}$ & 0.00 & 0.00 & 0.58 & 0.9 & 1.12 & 1.24 & 1.32 & 1.41 & 1.46 & 1.49 \\
\hline
\end{tabular}

Eq. 3

Eq. 4
When $\mathrm{n}$ indicates the size of the matrix, in this study, $\mathrm{n}=4$ and 3 for the main criteria and sub-criteria, respectively. Consistency index (C.I.) and consistency ratio (C.R.) can be determined, as shown in Eq. 3 and 4, respectively. This value can be calculated from the random index (R.I.), as clarified in Table 3, identified by Saaty vary on the matrix size $(N)$. An acceptable C.R. for rational decision-making suggested being lower than or equal to 0.1 [58]. Even though the consistency can identify the trustworthy, due to human based judgement, it is highly possible for the data to fall into inconsistency. Especially, the larger size of numbers of criteria can possibly result in inconsistency. In spite of the mentioned CR, in some cases, such as in a group evaluation, the C.R. between 0.1-0.2 is also acceptable [124]. Otherwise, the exceeding C.R. suggested to re-implement the criteria comparison.

Due to the allocated numbers of panelists in each group that was not equal in all sectors, the individual responses were taken for arithmetic average. This step was conducted within each organization group before calculating the overall mean values for all participants, as previously shown in the studies of experts participatory evaluation [123, 125].

Apart from the set of criteria as indicated in the pairwise comparison matrix, this study provided more opportunities for experts to select additional concerning points and suggest supplementary criteria, which are considered important in the respective context. 
The experts participated from 5 different fields; governmental sectors, industrial sectors, non-profit/non-governmental organization, academic/research institutes, and financial organizations. For the survey conduction in the first round, total 20 respondents from 29 contacted targets consented to attend in the survey participation. The selected experts' fields covered all range of associated players in the bioethanol production chain in Thailand within the boundary of origin of resources to bioethanol production. However, as the governmental section works closely as a facilitator and regulator of the private sectors, they are more familiar to the vital policy making, reflecting to the major proportion of governmental experts structured in the experts panel.

Due to only few feedbacks were returned in the second round in this performed survey, the survey interval stopped until round two. As a process of round two, after informing the round one results, the surveys were sent to the participants, while 4 respondents (20\%) returned their responses, and only 2 participants made a modification of the answers from the first round. Regarding the marginal number of feedback in the second round, we terminated the further rounds of the survey. The numbers of round have been reported to be varied but found average at two to three rounds [126]. Many studies stopped at the secondround $[122,127]$. The ratio of respondents who responded to re-evaluate in the second round in this study is considered to be comparable ratio to previous Delphi-AHP research [128].

During the time of survey conduction, engagement with the organizations was the most challenging part. The regular organizational system limited the access to connect with the experts directly, but it needed to be delegated from the executive levels to responsible for survey answering. In this way, there was the circumstance that the persons neglected to reply since they did not feel their prominent role as a decision-maker to the topic. Nonetheless, according to the institutional system, the delegation could guarantee that the participants are well qualified to responsible for the task. Meanwhile, regarding the limitation, we managed the lack of engagement by constantly revising the approach, such as attempts to communicating more frequently, providing insightful information, and searching for alternative ways of personal connection. In some cases, especially from the private firms, the decision to attend the survey were taken based on their core business of the institutes. This means that the enterprise's background is one of the explainable reasons for not being able to commit to every contacted respondent.

The result from round one and round two did not significantly differentiate results since only small numbers of the returning responses in round two. The participated organizations with numbers of the respondent are summarized in Table 4. As categorized by branches of expertise, proportions of participants are shown in Figure 3, elaborating that the structure of expert panels comprises of 6 experts from governmental sectors, 5 experts from private sectors, and 3 experts from each Non-Profit Organization NPO/NGO, academic and financial institute. 


\begin{tabular}{|c|c|c|c|c|}
\hline Type of Organization & $\begin{array}{l}\text { Contacted } \\
\text { numbers }\end{array}$ & $\begin{array}{l}\text { Number of } \\
\text { respondents } \\
\text { (round one) }\end{array}$ & $\begin{array}{l}\text { Number of } \\
\text { respondents } \\
\text { (round two) }\end{array}$ & $\begin{array}{c}\text { Proportions } \\
\text { [\%] }\end{array}$ \\
\hline Government / Ministry / Policymakers & 8 & 6 & - & 30 \\
\hline Industry / Business sectors & 10 & 5 & - & 25 \\
\hline $\begin{array}{l}\text { Non Profit Organization (NPO) / } \\
\text { Non Governmental Oganization (NGO) }\end{array}$ & 3 & 3 & 1 & 15 \\
\hline Academic / Research Institute & 4 & 3 & 2 & 15 \\
\hline Financial institution / Bank & 4 & 3 & 1 & 15 \\
\hline Total & 29 & 20 & 4 & 100 \\
\hline
\end{tabular}

2

Backgrounds of expertise were undertaken in order to breakdown the reasons for supporting the results, which was expected to assist in the interpretation of the AHP with the empirical factors of different backgrounds. Figure 3 illustrated the proportions 5 of panelists from diverse branches of familiarity with the topics and professional categories. It is notable that the participants 6 are majorly accustomed to the topics of energy policy and agricultural production. The second most allocated background was 7 in bioethanol or biofuel production.

8

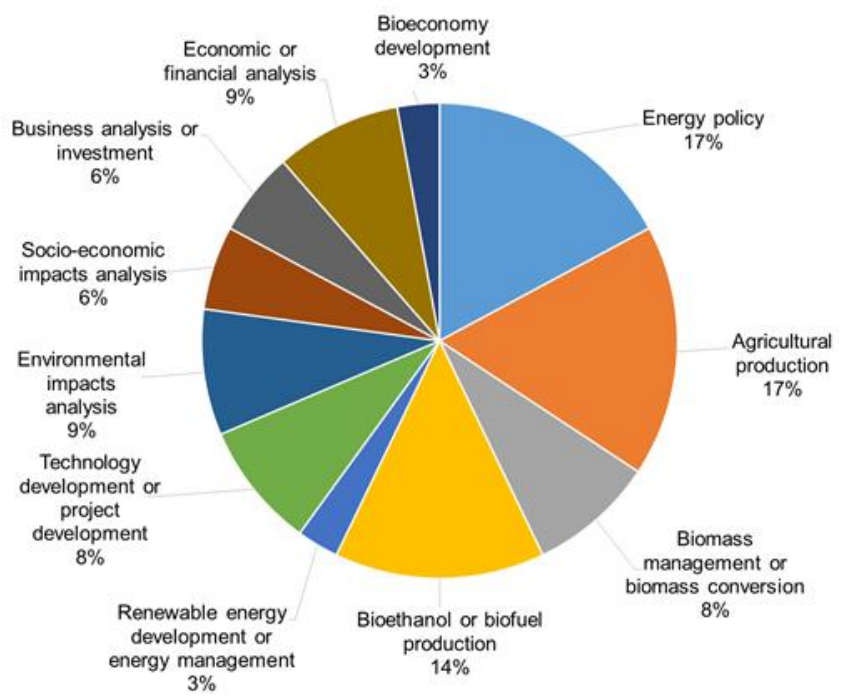




\section{Results of AHP analysis}

\section{Prioritization of main criteria}

Results of the relative weights of the main criteria from round one to round two showed slight changes. However, the ranking of preferable main criteria remained the same. The result of relative weights from the second round is shown in Figure 4. Based on the scores of pairwise comparison from every respondent, the Consistency Index (C.I.) was ranging from 0.000 0.074, whereas the calculation of Consistency Ratio (C.R.) resulted in between $0.000-0.083$. According to Saaty, if the C.R. is $<0.1$, the answers of evaluation by all participants were verified to be consistent. Among the four main criteria as the overall weight presented in Figure 4, 'Economic feasibility' gained the highest priority (32.3\%). Following that, the second and third ranks were resulted in 'Environmental impacts' (25.6\%) and 'Technical feasibility' (24.0\%), respectively. Lastly, the criteria weights for 'Social impacts' resulted in the least important (18.1\%).

When considering the scores of preferable criteria by categorizing based on expert panels, it is noticeable that the results could be divided into two groups. First, the group of governmental organizations, industry/business sectors, and financial institutes, where the 'Economic feasibility' showed noteworthy high scores. The other was the expert groups that prioritized 'Technical feasibility' as the most preferable, as found in NPO/NGO and academic or research institutes.

Comparing 'Environmental impacts' and 'Social impacts', except for the group academic/ research institute, most of the experts rated the 'Environmental impact' as more important than the latter. Interestingly, NPO/NGO showed more attention to the technical aspects, as it can be seen the merely higher scores than those from economic and environmental criteria. On the other hand, the industry and business sectors gave higher prioritization for economic and environmental aspects, comparing to technical and social dimensions.

Academic/Research
NPO/NGO




\section{Prioritization of sub-criteria}

The second level of criteria was assessed as sub-criteria, which interconnected to the four main subjects, as mentioned in 3.2.1. From the criteria evaluation of the first round and adjustment from the second round, the average values of sub-criteria weighting were obtained from 20 respondents. As a result of the consistency analysis, the average values of C.I. were calculated from sub-criteria in four main-criteria; technical, economic, social and environmental aspects, resulted in 0.011, 0.017, 0.008, and 0.007 , respectively. Meanwhile, the average values of C.R. were computed to be $0.019,0.030,0.014$, and 0.014 from the same respects. The results of C.R. from all participants in the evaluation of the sub-criteria have proved the consistent level in the study.

The results of normalized evaluations of overall sub-criteria are shown in Figure 5. The top three priorities were occupied by the sub-criteria from 'Economic feasibility' and 'Environmental impacts'. The highest priority was voted from 'Final price per liter of ethanol' (12.8\%), following by 'Added value of input materials' (11.7\%) and 'Net energy balance' (11.3\%). On the other hand, the sub-criteria 'Food security' (6.2\%) and 'Job creation' (4.5\%) from 'Social impacts' were prioritized at the lowest two criteria.

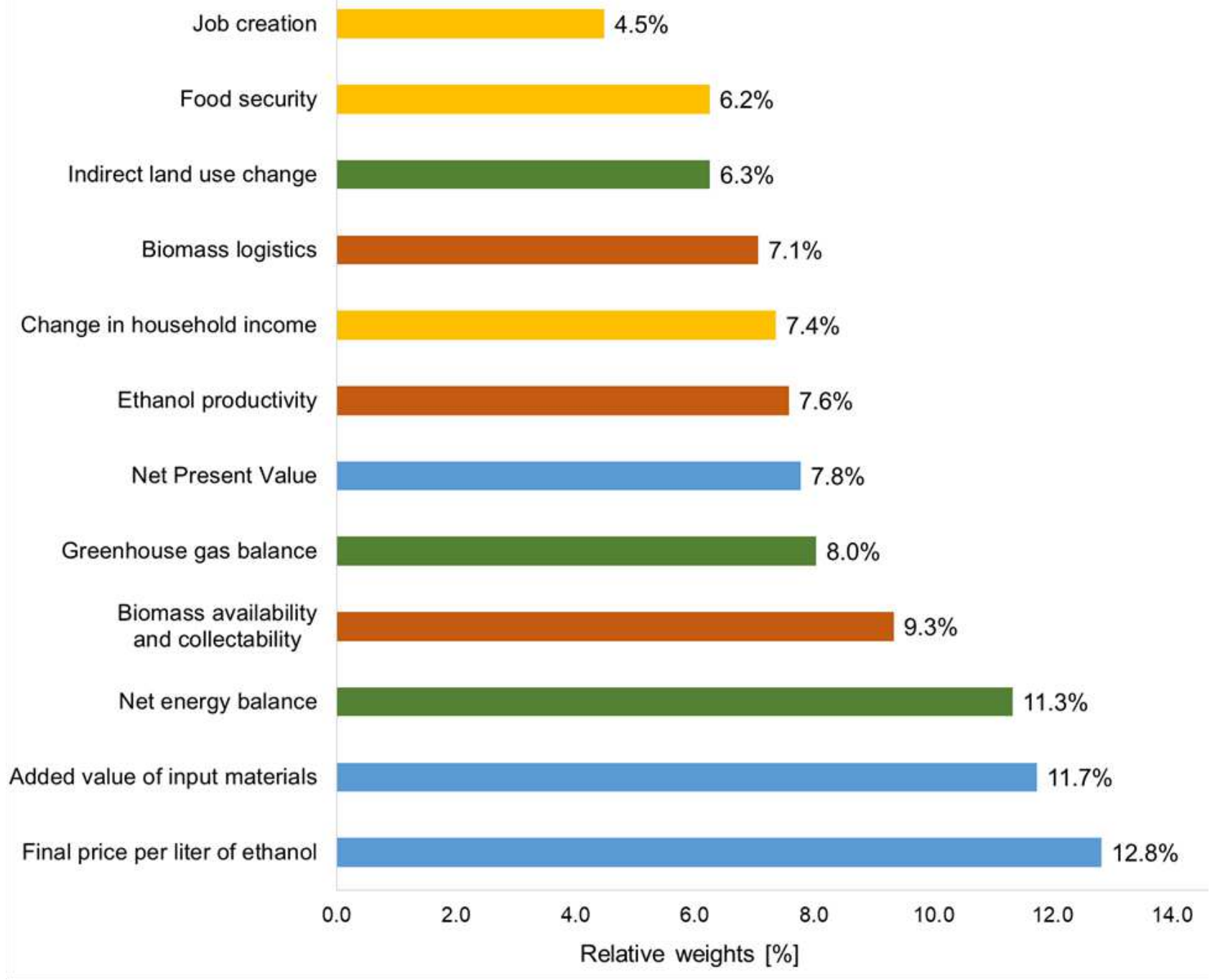


Table 5 presented the relative weights in respective main-criteria and overall relative weights of sub-criteria. The minimum and maximum weights were clarified with the values of standard deviations in order to indicate the range of voted scores by experts. From the comparison of criteria in the aspect of 'Technical feasibility', the 'Biomass availability and collectability' showed the highest weighting scores $(38.9 \%)$. This result could be related to the fact that second-generation bioethanol heavily depends on the quantity of agricultural residues considered to have a scattered availability. The result was identical to the weight for technical factors evaluated in the study of Kheybari et al [123]. Kheybari described reasons to support the importance of biomass availability that the factor of availability is associated with the logistic feasibility from biomass sources to the demand side.

In the dimension of economic feasibility, the experts prioritized 'Final price per liter of ethanol' as the most important criteria $(39.6 \%)$. This outcome identified the concern regarding the production cost of biofuel prices from agricultural residues. The concern was considered to be logical from the current status due to the fact that it is an under-commercialized technology in Thailand, implying the lack of referenced market prices.

Next, 'Change in household income' was the most dominant criterion from the social impacts. According to the study of von Doderer et al., employment income regarding a factor in socio-economic aspect could be determined based on the selling of products, or from selling power generation [117]. Payment to households could be an intriguing reason for the local people to accept a novel technology for the reason that the project can be related to the thriving economy in that local area [129]. indicates the efficiency and effectiveness of energy conversion from the biomass, influencing carbon emissions [130]. The process of biofuel production affects the ratio of input and output of energy. With the energy indicator, it is possible to justify the sustainability level between renewable biofuel and the conventional fuel [131].

Table 5 Summary of relative weights of main-criteria and sub-criteria weights as analyzed in this study

\begin{tabular}{|c|c|c|c|c|c|c|c|}
\hline Main-criteria & $\begin{array}{l}\text { Relative } \\
\text { weights }\end{array}$ & Sub-criteria & $\begin{array}{l}\text { Relative } \\
\text { weights }\end{array}$ & $\begin{array}{c}\text { Overall } \\
\text { Relative weight }\end{array}$ & $\begin{array}{c}\text { Min. } \\
\text { weights }\end{array}$ & $\begin{array}{c}\text { Max. } \\
\text { weights }\end{array}$ & $\begin{array}{c}\text { Standard } \\
\text { deviation } \\
\text { (SD) }\end{array}$ \\
\hline Technical & $24.0 \%$ & Biomass availability & & & & & \\
\hline \multirow[t]{4}{*}{ feasibility } & & and collectability & $38.9 \%$ & $9.3 \%$ & $1.8 \%$ & $17.4 \%$ & $5.38 \%$ \\
\hline & & Ethanol productivity & $31.6 \%$ & $7.6 \%$ & $1.6 \%$ & $16.6 \%$ & $5.62 \%$ \\
\hline & & Biomass logistics & $29.5 \%$ & $7.1 \%$ & $1.7 \%$ & $17.9 \%$ & $6.07 \%$ \\
\hline & & sub total & $100.0 \%$ & & & & \\
\hline Economic & $32.3 \%$ & & & & & & \\
\hline feasibility & & $\Lambda$ & $24.1 \%$ & $7.8 \%$ & $2.2 \%$ & $22.4 \%$ & $6.87 \%$ \\
\hline
\end{tabular}


Final price per liter of

ethanol

Added value of input

materials

sub total

$100.0 \%$

\begin{tabular}{|c|c|c|c|c|c|c|c|}
\hline \multirow[t]{5}{*}{ Social impacts } & \multirow[t]{5}{*}{$18.1 \%$} & Job creation & $24.8 \%$ & $4.5 \%$ & $1.3 \%$ & $12.4 \%$ & $3.47 \%$ \\
\hline & & Food security & $34.5 \%$ & $6.2 \%$ & $1.2 \%$ & $13.1 \%$ & $4.03 \%$ \\
\hline & & Change in household & & & & & \\
\hline & & income & $40.7 \%$ & $7.4 \%$ & $3.4 \%$ & $13.2 \%$ & $3.66 \%$ \\
\hline & & sub total & $100.0 \%$ & & & & \\
\hline \multirow{6}{*}{$\begin{array}{l}\text { Environmental } \\
\text { impacts }\end{array}$} & \multirow[t]{6}{*}{$25.6 \%$} & Indirect land use & & & & & \\
\hline & & change & $24.4 \%$ & $6.3 \%$ & $1.9 \%$ & $16.2 \%$ & $5.12 \%$ \\
\hline & & Greenhouse gas & & & & & \\
\hline & & balance & $31.4 \%$ & $8.0 \%$ & $2.7 \%$ & $17.7 \%$ & $5.19 \%$ \\
\hline & & Net energy balance & $44.2 \%$ & $11.3 \%$ & $1.8 \%$ & $18.3 \%$ & $5.86 \%$ \\
\hline & & sub total & $100.0 \%$ & & & & \\
\hline
\end{tabular}

Total $100.0 \%$ $100.0 \%$

1

Besides the overall criteria prioritization, the sub-criteria weights were categorized separately into types of organizations and branches of backgrounds (see Figure 6). In Figure 6, the relative weights of 12 sub-criteria were classified in the 5 groups of experts. Meanwhile, Figure 7 presented the Sankey diagram showing the relation between different backgrounds with organizations of participants, connecting to diverse results of criteria priority.

The highest priority of criteria from the experts in the Financial institutes/Bank was significantly occupied by 'Final price per liter of ethanol' $(22.5 \%)$. This result reflected the viewpoint that the biofuel prices must be considered in the project initiation of second-generation bioethanol. In general, banks consider the project potential from NPV and IRR, which will result in the decision in financial loan to the investors for newly constructed projects or factories [132].

Following that, for the academic and research institutes, the factor 'Biomass availability and collectability' was voted for the highest priority (13.3\%). Surprisingly, even though the representatives from academic institutes were allocated from the background of the environment, the concerns on environment related topics were relatively lower than expected. Similarly, the results of the highest priority evaluated by the NPO and NGO also emphasized the importance of 'Biomass availability and collectability' from the technical aspect (19.6\%). Regarding the results from the industry and business sector participants, although the proportions of main criteria were dominated by 'Economic feasibility', the largest percent of sub-criteria was 'Net energy balance' $(15 \%)$ from the category of environmental impacts. 
Unlike the other organizations, the governmental sector showed similar proportions in each criterion in terms of relative weights allocation. There was no significantly high proportion among 12 attributes; however, the highest score was the 'Final price per liter of ethanol' (13.7\%). The retail price of biofuel affects governmental subsidization since Thailand uses the mechanism to maintain the price gap between biofuel type and fossil fuel to promote consumption of renewable energy [133].

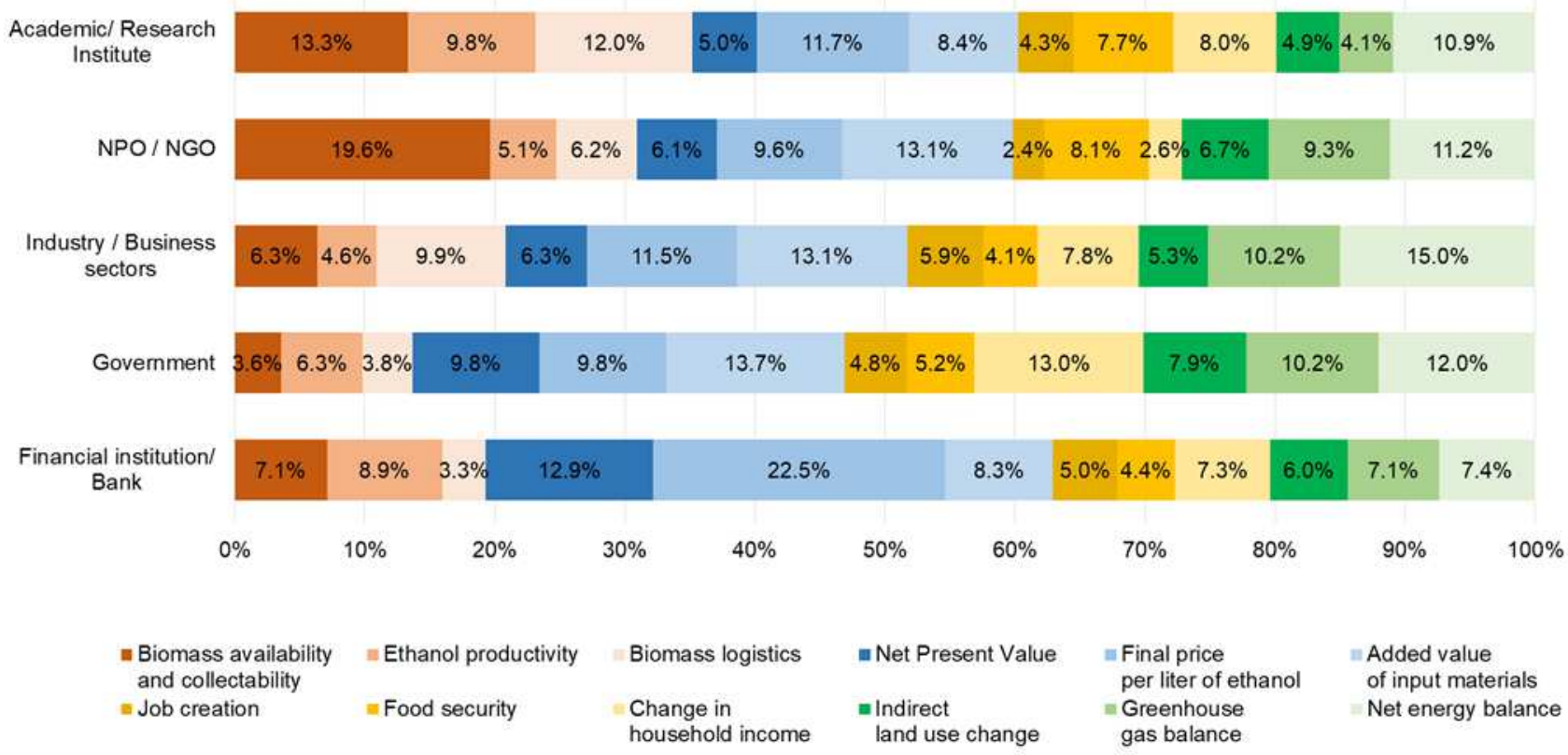

8 Figure 6 Relative weights for each sub-criteria as categorized by stakeholders in this study

9

\section{Connection between the expertise backgrounds, organizations and prioritized criteria}

For more understanding of the results regarding the expert judgement, the participants' backgrounds were collected as inquired in the questionnaire form. Figure 7 showed the connection between the experts' backgrounds, their affiliations, together with the outcomes of prioritization, constructing in the Sankey diagram. As a result of illustration, it was not possible for one participant from an organization to hold expertise in every subject. Nonetheless, all survey respondents could cover all necessary fields to fulfill the elements of value chain in this study. According to the survey results, the most associated fields of experts are in 'Energy policy' (17\%) and 'Agricultural production' (17\%), following by 'Bioethanol or biofuel production' (14\%). On the other hand, the least familiar topics for all participants were 'Renewable energy/energy management' (3\%) and 'Bioeconomy development' (3\%).

Interestingly, despite the results that the respondents from the governmental and academic sectors did not hold the expertise in the financial or business analysis, the most weighted criteria were reflected to 'Final price per liter'. Considering this preference, it is assumable that the participants might view the criteria 'Final price per liter' from different angles of pain 
points or requirements. For instance, this parameter could be interpreted as the profitable rate for the ethanol manufacturers, whereas the ethanol price can indicate the necessary incentive to persuade consumers from the governmental perspectives. Looking at the connection between the highest voted criteria under each organization (Figure 6) and the relationship with their backgrounds (Figure 7), most of the participants from Academic/research hold the background of 'Technology and project management' - voted for 'biomass availability and collectability' to be the most important. A similar result can be seen from NPO/NGO, with the majority of backgrounds in 'Environmental impacts analysis' gave the highest priority to the same criteria. The NPO/NGO were the organizations that engaged significantly with broad topics, including environmental, bioethanol, energy policy, agriculture, and socio-economic aspects. The output from the NPO/NGO is motivating to involve their perceptions in the early stage of policy-making process in order to avoid a possible disagreement towards public policy implementation.

Meanwhile, the experts from Industry and business sectors are associated mostly with 'Bioethanol and biofuel production' as well as 'Energy policy'. Their prioritized criteria went to 'Net energy balance' from the environmental aspect.

Following that, the most voted variable from the experts in the governmental sectors was 'Added value of input materials', although it can be seen that the related backgrounds were mainly located in 'Energy policy' and 'Agricultural production', which are not directly connected to the economic aspect. In comparison to the results from other organizations, the stakeholders evaluated criteria from overall participants.




1 Figure 7 Sankey diagram for illustrating the relationship between the categories "Field of expertise", "Type of organization" and "Criteria

2 weights" as derived from the Delphi-AHP results

3

Additional criteria and supplementary comments

Besides the pairwise comparison from the provided criteria, the participants were asked to select the relevant criteria 6 from multiple lists of topics. The aim of compiling additional criteria is to explore other possible elements from the sentiments of stakeholders. The additional criteria are expected to contribute to designing the implications of scenarios in the further steps studies.

The summary of further remarks is summarized in Table 6. It is remarkable that the most frequently selected criterion by all participants was 'Dependence on subsidy'. The most attention receiving factor emphasized the perceptions towards the role of government in the policy recommendation. Unsurprisingly, the technology readiness level resulted in the second most votes. Regarding the current status that the second generation bioethanol progressed at the pilot scale-production, the result suggested that it might still be too early for projection from their perceptions.

The second and third most voted additional criteria were derived from technological feasibility, namely 'Technology readiness level' and 'Co-products'. On the other hand, it is noticeable that the environment related criteria gained rather limited priority, such as output wastes, forest areas, and fertilizers/ pesticides. In addition, the social aspect criterion, 'Job quality', was voted by only one score. The results of additional criteria in this part have demonstrated overlapping results to the sub-criteria evaluation.

Table 6 Frequency of mentioned topics as additional criteria

\begin{tabular}{|c|c|c|c|c|c|c|}
\hline \multirow{3}{*}{ Mentioned topics } & \multirow{3}{*}{ Government } & \multicolumn{2}{|l|}{ Industry / } & \multirow{2}{*}{$\begin{array}{l}\text { Academic/ } \\
\text { Research }\end{array}$} & \multicolumn{2}{|l|}{ Financial } \\
\hline & & Business & $\mathrm{NPO} / \mathrm{NGO}$ & & institution/ & Total \\
\hline & & sectors & & Institute & Bank & \\
\hline Governmental subsidy & 3 & 2 & 2 & 1 & 3 & 11 \\
\hline Technology readiness level & 2 & 2 & 1 & 2 & 2 & 9 \\
\hline Co-products & 3 & 1 & 1 & 2 & 1 & 8 \\
\hline Air pollution level & 1 & - & 2 & 3 & 1 & 7 \\
\hline Water management and & 1 & 1 & 1 & - & 2 & 5 \\
\hline irrigation system & & & & & & \\
\hline Material balance & - & 1 & - & 2 & 1 & 4 \\
\hline Output wastes & 1 & 1 & 1 & - & 1 & 4 \\
\hline Forest areas & 1 & - & 1 & - & 1 & 3 \\
\hline Fertilizer and pesticides & - & 1 & 1 & - & - & 2 \\
\hline
\end{tabular}


1

Supplementary comments were compiled from the participants' opinions simultaneously in the surveying process. The comments were summarized and elaborated by groups of experts in Table 7. It is noticeable that the raised-up viewpoints reflected the insights based on their experiences. Some comments hinted at the underlying issues that should be properly discussed across multi-sectors. As it can be noticed from the comments, the governmental role is crucial for endorsing the strategic development of bioenergy. This involves governance-related elements, including laws and regulations that can support the upcoming advanced technology and, more importantly, the incentivized system structure. Meanwhile, the participants also emphasized the importance of competitiveness in the biofuel market from economic perspectives, which needs to be approached for biofuel producers and market expansion for bioenergy. Moreover, several have mentioned factors, which have not been provided in the current study, such as risk management and ethanol quality. Nonetheless, due to the concerns regarding under commercialized status, the technical feasibility would need to be verified as a transformation threshold. These retrieved comments were deemed to be valuable for creating future scenarios and evaluating for further study.

Table 7 Supplementary remarks from the participants categorized in branch of experts

Group of experts $\quad$ Supplementary comments

Government "Appropriate fuel price structure needs to be clarified."

"Incentive by the government to promote project initiation."

"Ethanol quality to be blended with the gasoline needs to be controlled for the reliability."

"Mechanism analysis to drive the expansion of the biofuel market."

"Products from the agricultural residues should not limit to only biofuel production, but the technology for value-added products should be integrated into the value chain."

"Wastewater treatment should be concerned in the process." 
"Even though the viability in the financial terms could be confirmed, technological feasibility is the imperative issue that has to be achieved."

"The comprehensive study on risk management for commercialization of the secondgeneration bioethanol technology."

Financial institution/ Bank

"The criteria evaluation in the study is mainly focused on the supply side; however, the criteria evaluation from the demand side, which can influence ethanol consumption, should also be taken into consideration."

"It is still questionable regarding the possibility for the advanced bioethanol to complying with the current law and regulations."

"Is the level of competitiveness between the bioethanol producing corporates high enough?"

1

\section{Discussion}

3

4

With the tool of Delphi-AHP, as demonstrated in the current research, it has been verified that the qualitative perceptions from 20 stakeholders could be transformed into quantifiable criteria. Diverse opinions depicting scattered attitudes towards the topic could become reconciled. Moreover, the participatory evaluation, as practiced in this study through Delphi-AHP, has emphasized the stakeholders to recognize the importance of their roles in the policy launching process, which encourages transparency and engagement to the creation of sustainable policy. The additional criteria and supplementary comments raised from the participants have identified the experts' understandings and concerns in regards to the topics.

Regarding the most attentive aspect that was voted for economic feasibility, the reflection from the respondents to economic viability could be contemplated from the supply and demand side. The supply side was likely inferred to the concerns towards investment cost and financial attractiveness due to new emerging technology. A similar result was also remarked in the literature studies that the investment cost is the most critical criterion for the economic aspect [111]. For the demand side, fuel price instability could be a matter of concern for consumers. Belonging to the economic aspect, the biofuel price was the most focused factor from overall relative weights.

When considering the cost structure of bioethanol, the raw material price can influence 40 - $60 \%$ of the minimum selling price [134]. Thus, the changing of biomass prices may majorly cause the fluctuation of biofuel selling prices. In addition, the declining crude oil price since 2015 could be possible to lead to the competitiveness with the final price per liter of bioethanol. In this sense, the selling price is a crucial driver for biofuel policy to encourage the willingness of the consumers to choose renewable energy over fossil fuel. Similar outcomes were remarked in the SWOT analysis by Chanthawong et al. for the case 
study of first-generation bioethanol production, mentioning that the price fluctuation of input materials was indicated as a weakness in the bioethanol policy development [37].

One of the economic mechanisms to support the market of low carbon fuels is to initiate the carbon pricing system on fossil fuels [135]. This strategy could bring successful results in many countries to stimulate the consumption of biofuel and reach the $\mathrm{CO}_{2}$ reduction goal from fossil based fuel consumption [135]. However, it was assessed that the carbon tax imposing on fossil fuel should be introduced as financing for biofuel consumption in order to stimulate the biofuel penetration in the market [136]. Thailand is one of the countries where the enforcement of carbon taxation has been under consideration. Ministry of Natural Resources and Environment of Thailand proposed instruments, such as the carbon taxation or carbon pricing system in Climate change master plan 2015-2050 [137]. Until now, Thailand has embarked on the experiment as a pilot project, which has been launched to exercise the carbon trading scheme among industries, public and private sectors [138].

However, the concept of levying carbon pricing or taxation on fossil fuels has been investigated to have an impact on higher products price; hence it would also affect the higher expenditure for the household [139]. The conceptual idea of carbon pricing for fossil fuel and the taxation to the vehicles has been proposed to the Ministry of Energy; however, it has not been approved at the decision-making level regarding the reason that it could increase gasoline price. The controversy occurred because of the concern regarding an effect on increasing commodity price that would become a burden for the consumers. This has been a significant bottleneck to promote economic instruments for GHG mitigation [140].

Considered to be the second-highest relative weights, the factor of added value in biomass emphasized the stakeholders' perception to enhance the value of agro-materials. The valorization of residual biomass has been put more effort to extend for the higher valuable production system in Thailand; however, the current technologies have been majorly implemented to only primary products, such as animal feeds, fertilizers [22], and fuel for combustion in the electricity generation [141, 142]. Until now, the commercialization of lignocellulosic ethanol has still been doubted for the competitiveness with fossil fuel due to the production cost. Nonetheless, it was proposed for a feasible commercialization model by developing the ethanol production, along with biorefinery products [28], which would be a motivation to extend the value chain of agricultural products and promote the agricultural residues for the bioeconomy development [29].

Next, the main-criteria of environmental impacts was the second most significant dimension, while the net energy balance, which is one of its sub-criteria, was voted to be the third-highest criterion of overall relative weights. Not only does the definition of this criterion have a boundary in environmental terms, but it is also related to technical feasibility, which can guarantee the energy gain from a whole process [104, 143]. As the assessment of the net energy ratio of the agricultural residues in cellulosic ethanol production has been verified for positive values, the potential of production technology and environmental benefits have been indicated. Nonetheless, different types of raw materials associated with various numbers of net energy balance and $\mathrm{CO}_{2}$ emission. Subsequently, selection for optimal input materials would be benefit for an analysis for to lessen the level of life cycle greenhouse gas [104, 143]. 
Regardless of the preferred aspect that the environmental impacts were highly ranked as the second priority, the factors of land use change and GHG balance did not stand out at the top ranking of overall sub-criteria scores. Significantly, the criteria regarding indirect land use change gained relatively low recognition from the governmental sectors, which are the key players in the policy-making process. Currently, deforestation still has been remarked as a constant issue [144]. Despite the fact that there is a forest preservation law in Thailand, namely Forest Act, B.E. 2484 [145], the land use for the agricultural industry still affects food crops cultivation areas [144]. Moreover, sugarcane and rice farms burning are continually happening, causing severe air pollution [146]. It can be assumed from the results from the current study that the evaluation on the matter of indirect land use and GHG emissions from the plantation are unfamiliar fields for the policy-makers. As the study by Chanthawong et al. has pointed out the results from the survey study that cultivating land expansion could be one of the solutions for agricultural improvement for future scenarios [37]. Nonetheless, the land expansion and appropriate land use for cultivating energy crops remain an issue that needs to be clarified at the policy-level.

Meanwhile, the technical feasibility was voted as the third-ranked dimension. The scores for this criterion were mostly given by experts from academic/research institutes who hold background knowledge mainly in technology and project management, and from NGO/NPO with backgrounds in energy policy and agricultural production. Among the studied criteria, the biomass availability was ranked at the fourth important of overall relative weights. However, this criterion is also a critical factor for bioenergy promotion in Thailand, along with the importance of economic feasibility and environmental impacts because it refers to the capacity and potential to develop productions from a stable supply [147]. Spatial data with the density of available biomass would indicate the potential areas and optimal production scale [148], which also influences the economic analysis. This factor is considered to be a key driver in decision-making for project implementation [149].

The surprising outcome was the weight of social impacts as ranked at the fourth concerning dimension. Based on this, it is possible to illustrate that the awareness for the local benefits has not yet risen enough in the stakeholder's perspectives. According to the study of conventional ethanol production from sugarcane, the socio-economic advantage was elucidated for thriving the local economy on account of laboring employment and rural incomes [129]. However, from the results of the criteria evaluation in this study, job creation was the least concerning factor. The underlying background is regarded as the fact that the jobs in the agricultural sector in recent years have become less popular because of lower income in agriculture comparing with non-agricultural works [150]. One of the causes is considered that sugarcanes and cassavas cultivations are heavily influenced by the weather conditions and the traditional agricultural system (e.g., monoculture system) [150]; hence the farming job is volatile in terms of income from unpredictable productivity.

Not only the issue concerning fewer farmers working in agriculture, but unimproved production yields of sugarcane and cassavas could also be reflective feedbacks from the bottom-up assessment, which could draw awareness from the policymakers. Projecting for long-term sustainable development, it is necessary to address the investment of infrastructures, adequate irrigation systems, and technology for mechanizing agriculture to achieve higher value-added products. These are essential 
elements to transform the agricultural sector to the higher-level industry, as advised by the stakeholders in the supplementary remarks, and could also, in turn, endorse employment in this sector.

From the additional indicators, as voted in this study, the governmental subsidy was the most additionally selected criteria.

This implied that energy policy or energy-related initiation relied heavily on the economic aspect, as the subsidization or price incentive is the driver to be launched by the nation. In a sense, this result emphasized an essential role of government to incentivize biofuel system promotion. Thus far, the government incentive has been located at only the retail level by inducing the cross-subsidization scheme, subsidizing the biofuel selling price from non-blended fossil fuel selling [133, 151]. Nevertheless, considering the farmers' benefits, the price guarantee system for feedstocks providers or crops growers has remained concerned [147].

The utilization of cellulosic residues in the biorefinery for further products is a possible option to increase alternative incomes for the farmers and more channels to develop the higher-skilled labors in the agricultural sector [152]. One of the potential scenarios is the promotion of utilizing regional biomass, which could encourage mixed feedstocks, providing the possibilities to facilitate biomass handling and logistics [72]. Furthermore, as of the technological development corresponding to added-value and co-products, the end-products could be extensively recommended for biochemical production. One of the backgrounds is that the bioeconomy market is transforming over time, encouraging the biomass conversion technology to be established for a broad range of biorefinery products, which can be a plus for the industries to have more flexibility [153].

Even though the commercialization of second-generation bioethanol as an emerging technology still needs advancement from the private and research sectors, the participants have agreed that the policy mechanisms and regulations by the government are the necessary tools for long-term policy promotion. Especially from the governments and policy-makers points of view, the preferable concerns were focused on economic feasibility and environmental impacts. It can be summarized that in line with the verification on technological feasibility, the mechanisms from the government policy as well as the law and regulations are the keys to facilitate the technology developers and other relevant stakeholders to achieve the profitable investment and enhance the competitiveness in the market.

The findings highlighted the importance of financial feasibility and environmental impacts from the overall results of the prioritization. However, with respect to the results, it is also likely to determine that there are no significant differences between the four main-criteria. The priority would not be equal, but the evaluation should not focus on only one dimension. Regarding the fact that there is no perfect bioenergy strategy that would fit all requirements [55], the results as obtained from this study might be used as the initial step to developing second-generation bioethanol. Particularly, due to a long term field burn severity as seen in Thailand, the first focus that needs to be dealt with is the environmental aspects regarding the pollution from field burning, which could be promoted to deploy the unutilized agricultural residues. This perspective scenario is believed to be an opportunity for developing lignocellulosic biomass to promote the bioeconomy and mitigate environmental impacts. 


\section{Conclusions}

A development plan of bioethanol in Thailand has been promoted initially to substitute the imported fossil fuel and encourage agricultural crop production in the energy sector. However, biofuel production has focused very little on the aspects of socio-economic impacts and environmental side effects. In order to create a sustainable framework to meet the goal of bioethanol production and ensure the long-term benefits for related stakeholders, the multidisciplinary dimensions and criteria have become more necessary to be incorporated in the policy-making.

The participatory evaluation through the Delphi-AHP approach has accomplished the main objective of the study to prioritize the criteria for second-generation bioethanol development. The Delphi survey process verifies the advantage of anonymity in the survey conduction, which encourages the respondents to share their opinions openly. At the same time, the AHP technique has proved a convincing performance in transforming the subjective opinions into multi-criteria prioritization, which enables the present study to obtain the most reflective indicators representing transdisciplinary perceptions of experts. Even though the scattered perceptions from different backgrounds are commonly noticeable, the Delphi-AHP technique could reduce conflicts and provide agreeable results by the consenting process.

The findings from the study of criteria prioritization demonstrate the stakeholder's priority towards new generation bioethanol, suggesting the key indicators to be taken into consideration when putting the advanced technology forward to policy implementation. As a result, it is confirmed that the economic feasibility is the essential aspect of project analysis. Especially, the terms of the final selling price of bioethanol and improvement of the added value of raw materials are the keywords to focus on commercialization and policy recommendation. Even though the second-generation bioethanol technology is currently at the level of demonstration, indicating that comprehensive understandings about the technology are yet required, environmental and economic benefits are verified to be concerned factors in addition to demonstrating the technical feasibility.

The application of AHP did its work to reflect the perceptions regarding current concerns and the prospect of scenarios suggestion, which can be compatible with the future biofuel development in Thailand. The outcomes from the current analysis are believed to be references for creating a second-generation bioethanol analysis framework as a future step. With the integration of multi-dimensional perspectives from stakeholders, it is possible to construct an effective process for bioenergy policy to be consented by the stakeholders and attain the GHG mitigation goals, while the tradeoffs could be minimized. 


\section{Supplementary information}

Delphi-Survey Questionnaire

- the Prioritization of Criteria -

1. General information *

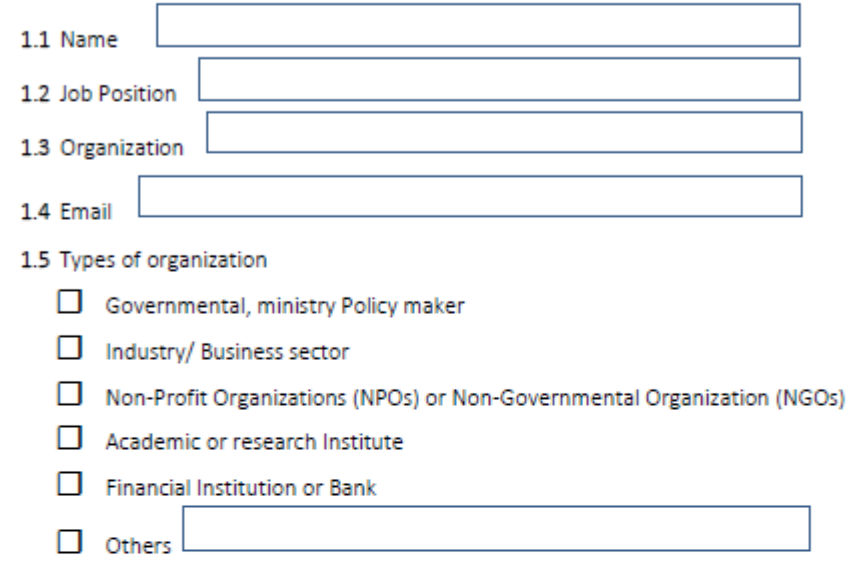

To which area fits your expertise/profession? (You can select more than one option)
$\square$ Energy policy
$\square$ Agricultural production
$\square$ Biomass management or biomass conversion
$\square$ Bioethanol or biofuel production
$\square$ Renewable energy development or energy management
$\square$ Technology development or project development
$\square$ Environmental impacts analysis
$\square$ Socio-economic impacts analysis
$\square$ Business analysis or investment
$\square$ Economic or financial analysis
$\square$ Bioeconomy development

$\square$ Others

4. Part I: Prioritization of the main criteria

Question: How should we prioritize the relevant aspects?

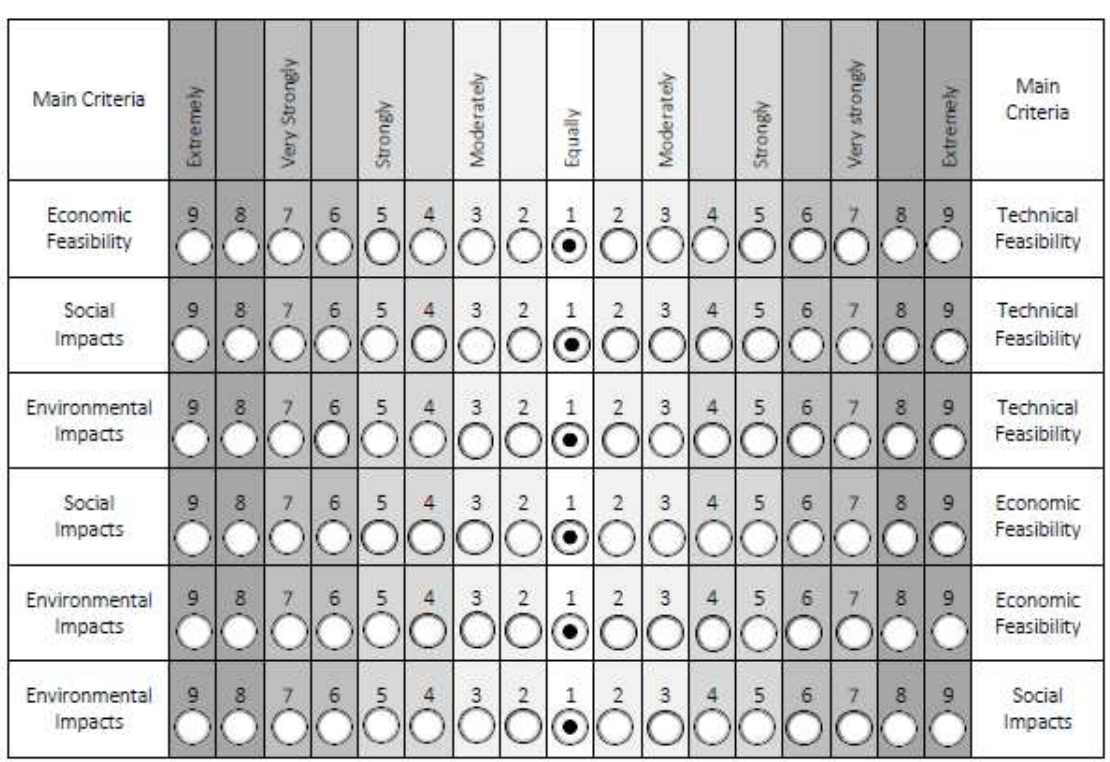




\section{Part II: Prioritization of the sub-criteria}

Please rate the importance of criteria considering each dimension.

5.1 Technical aspect

Question: How do you evaluate the technical feasibility?

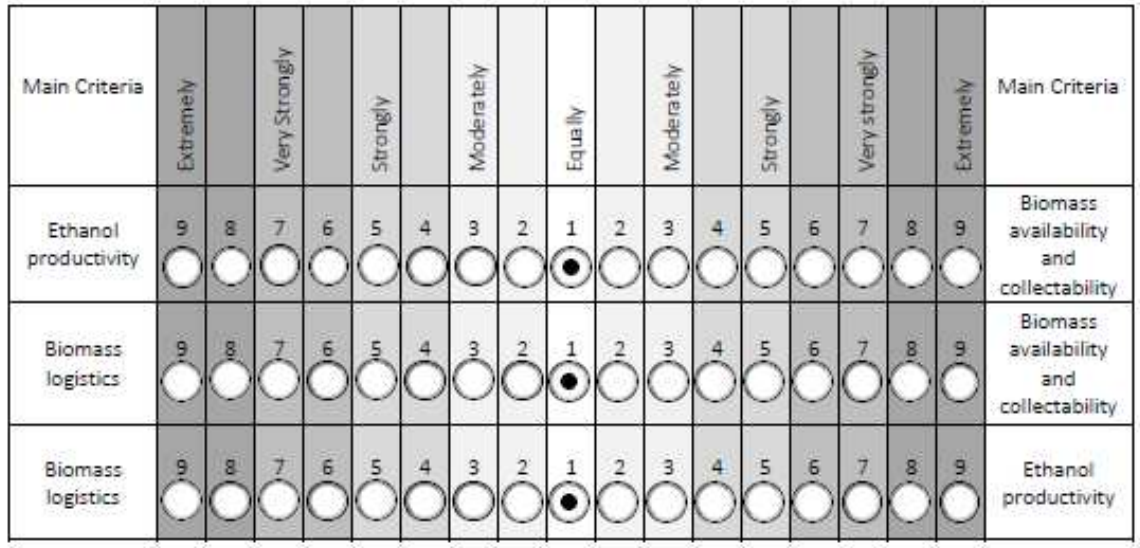

5.2 Economic aspect

Question: How do you evaluate the sub-criteria for economic feasibility?

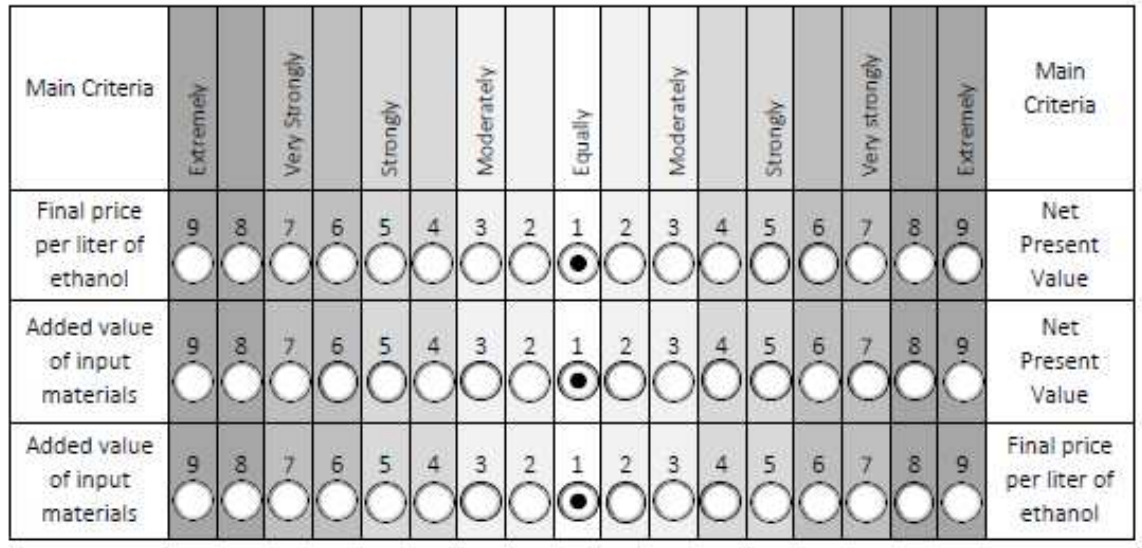


5.3 Social impacts

Question: How do you evaluate social impacts?

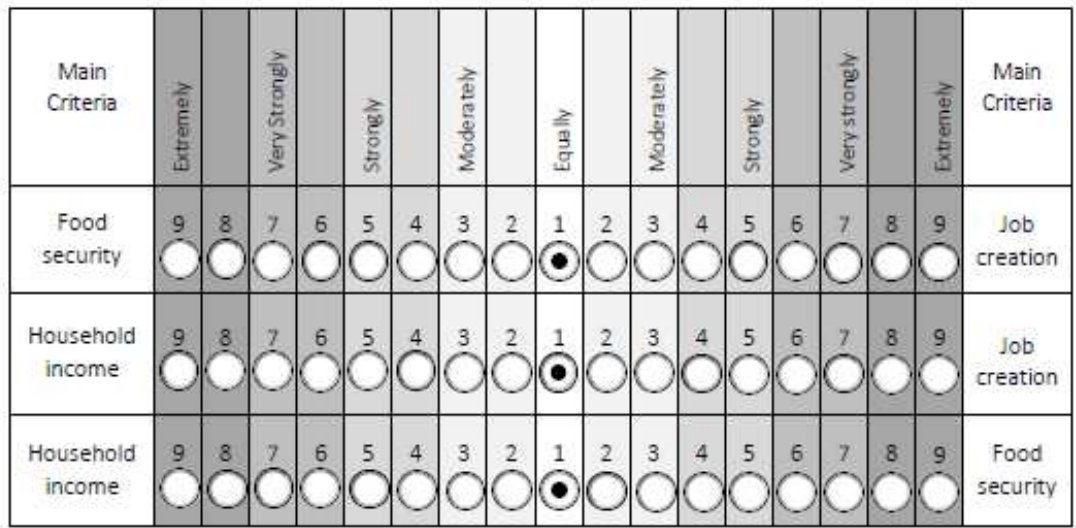

5.4 Environmental aspect

Question: How do you evaluate environmental effect?

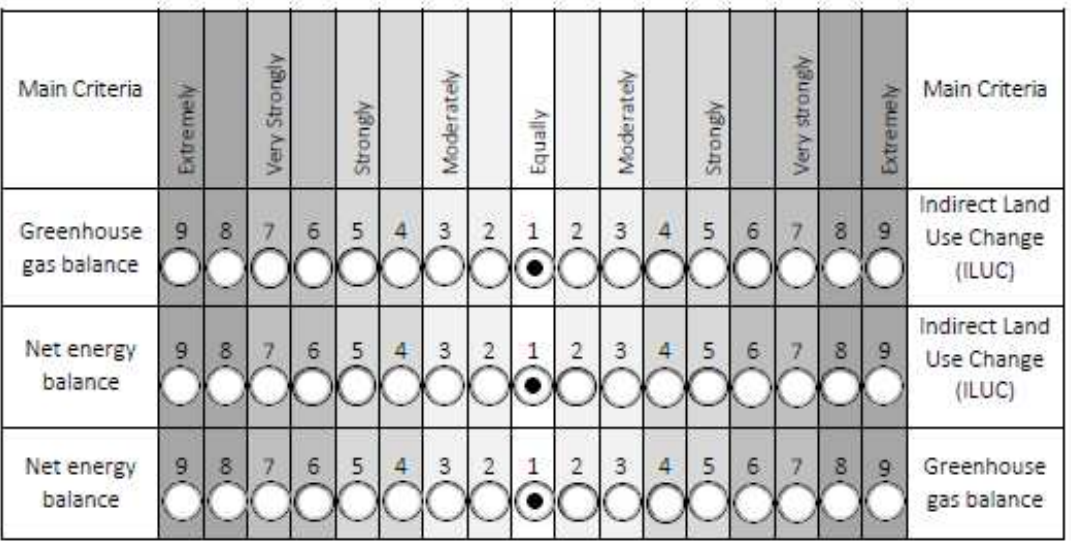




\section{PART III : Suggestion for further criteria}

In this step, the participants are able to, additionally, select further relevant criteria, if the above criteria are insufficient. Please select the additional important indicators

$\square$ Dependence on subsidy

$\square$ Distributed income

$\square$ Fertilizers or pesticides

$\square$ Water management and irrigation systems

$\square$ By-products

$\square$ Material balance

$\square$ Technology readiness leve

$\square$ Air pollution level (e.g. PM 2.5, PM 10)

$\square$ Output wastes

$\square$ Land prices

$\square$ job quality

$\square$ Forest areas

Other possible criteria

1

Please give us further comments or suggestions regarding the Delphi-Survey or the study.

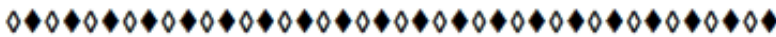

2

Thank you for your precious time to complete our survey.

3

4

5

6

7 


\section{Abbreviation}

2 GHG: Greenhouse gas emission; COP21: The twenty-first session of the Conference of the Parties; AEDP: Alternative Energy Development Plan; SDGs: United Nations Sustainable Development Goals; EU: European Union; MCDA: Multi-criteria decision analysis; AHP: Analytic Hierarchy Process; NPV: Net present value; IRR: Internal rate of return; iLUC: Indirect Land Use; NER: Net energy ratio; C.I.: Consistency Index; C.R.: Consistency ratio; R.I.: Random index; NPO: Non-Profit Organization; NGO: NonGovernmental Organization; SD: Standard deviation

\section{Acknowledgements}

8 The authors would like to express gratitude to all participants for taking part in this survey study. This research paper would not have been possible without every thoughtful evaluation and insightful opinions. The authors also acknowledge the Ministry of Energy Thailand for the doctoral scholarship of Jusakulvijit P.

\section{Ethics declarations}

12 Ethics approval and consent to participate

13 Not applicable

14 Consent for publication

15 All authors consented for this paper to be published.

\section{Competing Interest}

17 The authors declare no competing interest.

\section{Availability of data and materials}

19 The datasets generated and analyzed during the current study are not publicly available due to agreement of anonymity with 20 the respondents and privacy information concerns. However, they are available from the corresponding author on reasonable 21 request.

\section{$22 \quad$ Funding}

23 The project as part of the doctoral research was financed by Energy Conservation Promotion Fund (ENCON Fund) of the Royal 24 Thai Government, Ministry of Energy (Thailand).

\section{Author information}

\section{Affiliations}

27 1. Helmholtz Centre for Environmental Research - UFZ. Department of Bioenergy. Permoserstr. 15, 04318 Leipzig, Germany Piradee Jusakulvijit, Alberto Bezama \& Daniela Thrän 
Piradee Jusakulvijit \& Daniela Thrän

33 Deutsches Biomasseforschungszentrum gGmbH - DBFZ. Torgauerstr. 116, 04347 Leipzig, Germany

4 Daniela Thrän

5 Authors' contribution

P.J. and A.B. conceived the presented ideas. P.J. contacted the experts, conducted the survey, and executed data analysis. A.B. and D.T. supervised and edited the production of the manuscript.

8 Corresponding author

9 Correspondence to Piradee Jusakulvijit, E-mail: piradee.jusakulvijit@ufz.de

\section{References}

12 1. United Nations Framework Convention on Climate Change - UNFCC.: Thailand's Third National Communication. https://www4.unfccc.int/sites/SubmissionsStaging/NationalReports/Documents/52047631_Thailand-NC3-1Thailand TNC.pdf. Accessed 9 September 2020.

2. The Office of Natural Resources and Environmental Policy and Planning (2015) Thailand's Intended Nationally Determined Contribution (INDC). https://www4.unfccc.int/sites/ndcstaging/PublishedDocuments/Thailand First/Thailand_INDC.pdf. Accessed 9 September.

3. Energy Policy and Planning Office, Ministry of Energy Thailand (2015), Alternative Energy Development Plan : AEDP2015. http://www.eppo.go.th/index.php/en/policy-and-plan/en-tieb/tieb-aedp Accessed 5 November 2020.

4. Department of Energy Business, Ministry of Energy - Statistic data. https://www.doeb.go.th/2017/\#/article/statistic. Accessed 8 September 2020.

5. Food and Agriculture Organization of the United Nations (FAO) (2010) BEFS Thailand: key results and policy recommendations for future bioenergy development. http://www.fao.org/3/i1745e/i1745e.pdf. Accessed 10 September 2020.

6. Silalertruksa T, Gheewala SH, Sagisaka M (2009) Impacts of Thai bio-ethanol policy target on land use and greenhouse gas emissions. Appl Energy 86:S170-S177.

7. Chanthawong A, Dhakal S (2016) Stakeholders ' perceptions on challenges and opportunities for biodiesel and bioethanol policy development in Thailand. Energy Policy 91:189-206.

8. European commission (2014) Renewable Energy Directive. 
November 2020.

3 9. Popp J, Lakner Z, Harangi-Rákos M, Fári M (2014) The effect of bioenergy expansion: Food, energy, and environment. Renew Sustain Energy Rev 32:559-578.

10. Timilsina GR, Beghin JC, van der Mensbrugghe D, Mevel S (2010) The Impacts of Biofuel Targets on Land-Use Change and Food Supply A Global CGE Assessment. orld Bank Policy Research Working Paper WPS5513. World Bank, Washington, DC.

11. Lewandowski I (Ed) (2018) Bioeconomy: Shaping the Transition to a Sustainable, Biobased Economy. Bioeconomy Shap Transit to a Sustain Biobased Economy. First, Springer International Publishing. https://doi.org/10.1007/978$\underline{3-319-68152-87}$

12. European Commission (2018) A sustainable Bioeconomy for Europe: strengthening the connection between economy, society and the environment. https://doi.org/10.2777/478385. Accessed 2 November 2020.

13. Zeug W, Bezama A, Moesenfechtel U, Jähkel A, Thrän D (2019) Stakeholders' interests and perceptions of bioeconomy monitoring using a sustainable development goal framework. Sustain. https://doi.org/10.3390/su11061511

14. Hildebrandt J, Bezama A, Thrän D (2020) Insights from the sustainability monitoring tool SUMINISTRO applied to a case study system of prospective wood-based industry networks in central Germany. Sustain. https://doi.org/10.3390/su12093896

15. Bracco S, Tani A, Çalıcıoğlu Ö, Gomez San Juan M, Bogdanski A (2019) Indicators to monitor and evaluate the sustainability of bioeconomy. Overview and a proposed way forward. Rome, FAO.

16. Fachagentur Nachwachsende Rohstoffe (FNR). - Agency for renewable resources (2012) Biorefineries Roadmap as part of the German Federal Government action plans for the material and energetic utilisation of renewable raw materials. The German Federal Government, Berlin.

17. Jarosch L, Zeug W, Bezama A, Finkbeiner M, Thrän D (2020) A regional socio-economic life cycle assessment of a bioeconomy value chain. Sustain 12:1-15. doi:10.3390/su12031259.

18. Directorate-General for Research and Innovation (European Commission) (2015) Sustainable agriculture, forestry and fisheries in the bioeconomy. A challenge for Europe: 4th SCAR foresight exercise. https://op.europa.eu/en/publication-detail/-/publication/7869030d-6d05-11e5-9317-01aa75ed71a1. Accessed 10 October 2020.

19. Thrän D, Bezama A (2017) The knowledge-based bioeconomy and its impact in our working field. Waste Manag Res 
20. Valentine J, Clifton-Brown J, Hastings A, Robson P, Allison G, Smith P (2012) Food vs. fuel: The use of land for lignocellulosic "next generation" energy crops that minimize competition with primary food production. GCB Bioenergy 4:1-19. doi: 10.1111/j.1757-1707.2011.01111.x

21. Garivait S, Chaiyo U, Patumsawad S, Deakhuntod J (2006) Physical and Chemical Properties of Thai Biomass Fuels from Agricultural Residues. Sustain Energy Environ 048:48-1

22. Papong S, Yuvaniyama C, Lohsomboon P, Malakul P (2004) Overview of Biomass Utilization in Thailand, The meeting for LCA in ASEAN Biomass Project, International Conference Center EPOCHAL TSUKUBA, Japan.

23. Silalertruksa T, Gheewala SH (2013) A comparative LCA of rice straw utilization for fuels and fertilizer in Thailand. Bioresour Technol 150:412-419

24. Trakulvichean S, Chaiprasert P, Otmakhova J, Songkasiri W (2017) Comparison of fermented animal feed and

25. Chunhawong K, Chaisan T, Rungmekarat S (2018) Sugar Industry and Utilization of Its By-products in Thailand : An

26. Kanokkanjana K, Garivait S (2013) Alternative Rice Straw Management Practices to Reduce Field Open Burning in Thailand. Int J Environ Sci Dev 4:119-123.

27. Heo S, Choi JW (2019) Potential and Environmental Impacts of Liquid Biofuel from Agricultural Residues in Thailand. Sustain 11:1502.

28. Rosales-Calderon O, Arantes V (2019) A review on commercial-scale high-value products that can be produced alongside cellulosic ethanol. Biotechnol Biofuels 12:240 https://doi.org/10.1186/s13068-019-1529-1

29. Dahmen N, Lewandowski I, Zibek S, Weidtmann A (2019) Integrated lignocellulosic value chains in a growing bioeconomy: Status quo and perspectives. GCB Bioenergy 11:107-117.

30. van Eijck J, Batidzirai B, Faaij A (2014) Current and future economic performance of first and second generation biofuels in developing countries. Appl Energy 135:115-141.

31. Kami M, Barz M, Gheewala SH, Sajjakulnukit B (2012) Environmental and socio-economic feasibility assessment of rice straw conversion to power and ethanol in Thailand. J Clean Prod 37:29-41

32. Humbird D, Davis R, Tao L, Kinchin C, Hsu D, Aden A, Schoen P, Lukas J, Olthof B, Worley M, Sexton D, Dudgeon D (2011) Process Design and Economics for Biochemical Conversion of Lignocellulosic Biomass to Ethanol - DiluteAcid Pretreatment and Enzymatic Hydrolysis of Corn Stover. National Renewable Energy Laboratory, Technical 
Report NREL/TP-5100-47764. https://www.nrel.gov/docs/fy11osti/47764.pdf. Accessed 18 September 2020.

33. Elghali L, Clift R, Sinclair P, Panoutsou C, Bauen A (2007) Developing a sustainability framework for the assessment of bioenergy systems. Energy Policy 35:6075-6083

34. Colapinto C, Jayaraman R, Ben Abdelaziz F, La Torre D (2019) Environmental sustainability and multifaceted development: multi-criteria decision models with applications. Ann Oper Res. https://doi.org/10.1007/s10479-019$\underline{03403-y}$

35. Scott JA, Ho W, Dey PK (2012) A review of multi-criteria decision-making methods for bioenergy systems. Energy 42:146-156.

36. Løken E (2007) Use of multicriteria decision analysis methods for energy planning problems. Renew Sustain Energy $\operatorname{Rev} 11: 1584-1595$.

37. Chanthawong A, Dhakal S (2016) Stakeholders' perceptions on challenges and opportunities for biodiesel and bioethanol policy development in Thailand. Energy Policy 91:189-206.

38. Kumar S, Shrestha P, Abdul Salam P (2013) A review of biofuel policies in the major biofuel producing countries of ASEAN: Production, targets, policy drivers and impacts. Renew Sustain Energy Rev 26:822-836.

39. Supasa T, Hsiau SS, Lin SM, Wongsapai W, Wu JC (2016) Has energy conservation been an effective policy for Thailand? An input-output structural decomposition analysis from 1995 to 2010. Energy Policy 98:210-220.

40. Ellis J (2012) The Effects of Fossil-Fuel Subsidy Reform: A Review of Modelling and Empirical Studies. SSRN Electron J. https://doi.org/10.2139/ssrn.1572397

41. Lecksiwilai N, Gheewala SH (2020) Life cycle assessment of biofuels in Thailand: Implications of environmental trade-offs for policy decisions. Sustain Prod Consum 22:177-185.

42. Office of the Cane and Sugar Board (OCSB), Sugarcane production. http://www.ocsb.go.th/th/cms/detail.php?ID=142\&SystemModuleKey=production. Accessed 14 September 2020.

43. Office of Agrricultural Economics, Crops production. http://www.oae.go.th/view/1/Information/EN-US. Accessed 14 September 2020.

44. Silalertruksa T, Gheewala SH (2011) Long-term bioethanol system and its implications on GHG emissions: A case study of Thailand. Environ Sci Technol 45:4920-4928.

45. Alkimim A, Clarke KC (2018) Land use change and the carbon debt for sugarcane ethanol production in Brazil. Land use policy 72:65-73.

46. Kongboon R, Sampattagul S (2012) The water footprint of sugarcane and cassava in northern Thailand. Procedia Soc Behav Sci 40:451-460. 
47. Sornpoon W, Bonnet S, Kasemsap P, Prasertsak P, Garivait S (2014) Estimation of emissions from sugarcane field burning in thailand using bottom-up country-specific activity data. Atmosphere (Basel) 5:669-685.

48. Junpen A, Pansuk J, Kamnoet O, Cheewaphongphan P (2018) Emission of Air Pollutants from Rice Residue Open Burning in Thailand, 2018. Atmosphere 9:449.

49. Prasara-A J, Gheewala SH, Silalertruksa T, Pongpat P, Sawaengsak W (2019) Environmental and social life cycle assessment to enhance sustainability of sugarcane-based products in Thailand. Clean Technol Environ Policy 21:1447-1458.

50. Silalertruksa T, Gheewala SH, Hünecke K, Fritsche UR (2012) Biofuels and employment effects: Implications for socio-economic development in Thailand. Biomass and Bioenergy 46:409-418.

51. Wang MQ, Han J, Haq Z, Tyner WE, Wu M, Elgowainy A (2011) Energy and greenhouse gas emission effects of corn and cellulosic ethanol with technology improvements and land use changes. Biomass and Bioenergy 35:1885-1896.

52. Roy P, Tokuyasu K, Orikasa T, Nakamura N, Shiina T (2012) A Review of Life Cycle Assessment (LCA) of Bioethanol

53. Millinger M, Ponitka J, Arendt O, Thrän D (2017) Competitiveness of advanced and conventional biofuels: Results

54. Lynd LR, Liang X, Biddy MJ, Allee A, Cai H, Foust T, Himmel ME, Laser MS, Wang M, Wyman CE (2017) Cellulosic

55. Müller-langer F, Majer S, Keeffe SO (2014) Benchmarking biofuels - a comparison of technical, economic and environmental indicators. Energy Sustain Soc 4:20.

56. Huang IB, Keisler J, Linkov I (2011) Multi-criteria decision analysis in environmental sciences: Ten years of applications and trends. Sci Total Environ 409:3578-3594

57. Van Dam JEG, De Klerk-Engels B, Struik PC, Rabbinge R (2005) Securing renewable resource supplies for changing market demands in a bio-based economy. Ind Crops Prod 21:129-144

58. Saaty RW (1987) The Analytic Hierarchy Process - What it is and How it is used. Mathl Model 9 No. 3-5:161-176.

59. Kurka T (2013) Application of the analytic hierarchy process to evaluate the regional sustainability of bioenergy developments. Energy 62:393-402.

60. Wind Y, Saaty T (1980) Marketing Applications of the Analytic Hierarchy Process Author ( $\mathrm{s}$ ): Yoram Wind and Thomas L . Saaty Published by : INFORMS Stable URL : http://www.jstor.org/stable/2630699. Manage Sci 26:641658.

61. Ramanathan R, Ganesh LS (1995) Energy resource allocation incorporating qualitative and quantitative criteria: An 
62. Ribeiro LA, da Silva PP, Mata TM, Martins AA (2015) Prospects of using microalgae for biofuels production: Results of a Delphi study. Renew Energy 75:799-804.

63. Qu M, Ahponen P, Tahvanainen L, Pelkonen P (2010) Chinese academic experts' assessment for forest bio-energy development in China. Energy Policy 38:6767-6775.

64. Makkonen M, Pätäri S, Jantunen A, Viljainen S (2012) Competition in the European electricity markets - outcomes of a Delphi study. Energy Policy 44:431-440.

65. Linstone HA, Turoff M (2011) Delphi: A brief look backward and forward. Technol Forecast Soc Change 78:17121719.

66. Hasson F, Keeney S, McKenna H (2000) Research guidelines for the Delphi survey technique. J Adv Nurs 32:10081015.

67. Kharat MG, Raut RD, Kamble SS, Kamble SJ (2016) The application of Delphi and AHP method in environmentally

68. Junginger M, Faaij A, Van Den Broek R, Koopmans A, Hulscher W (2001) Fuel supply strategies for large-scale bio-

69. Chanthunyagarn S, Garivait S, Gheewala SH (2004) Bioenergy Atlas of Agricultural Residues in Thailand, The Joint energy projects in developing countries. Electricity generation from agricultural and forest residues in Northeastern Thailand. Biomass and Bioenergy 21:259-275. International Conference on "Sustainable Energy and Environment (SEE)", Huahin, Thailand

70. Viikari L, Vehmaanperä J, Koivula A (2012) Lignocellulosic ethanol: From science to industry. Biomass and Bioenergy $46: 13-24$.

71. Aden A, Ruth M, Ibsen K, Jechura J, Neeves K, Sheehan J, Wallace B, Montague L, Slayton A, Lukas J (2002) Lignocellulosic Biomass to Ethanol Process Design and Economics Utilizing Co-Current Dilute Acid Prehydrolysis and Enzymatic Hydrolysis for Corn Stover. National Renewable Energy Laboratory (NREL), Technical Report NREL/TP$510-32438$.

72. Zhu X, Yao Q (2011) Logistics system design for biomass-to-bioenergy industry with multiple types of feedstocks. Bioresour Technol 102:10936-10945.

73. Vijay Ramamurthi P, Cristina Fernandes M, Sieverts Nielsen P, Pedro Nunes C (2014) Logistics cost analysis of rice residues for second generation bioenergy production in Ghana. Bioresour Technol 173:429-438.

Delivand MK, Barz M, Gheewala SH (2011) Logistics cost analysis of rice straw for biomass power generation in Thailand. Energy 36:1435-1441. 
75. Gan J, Smith CT (2011) Optimal plant size and feedstock supply radius: A modeling approach to minimize bioenergy production costs. Biomass and Bioenergy 35:3350-3359.

3 76. Alex Marvin W, Schmidt LD, Benjaafar S, Tiffany DG, Daoutidis P (2012) Economic Optimization of a Lignocellulosic Biomass-to-Ethanol Supply Chain. Chem Eng Sci 67:68-79.

77. Dantas GA, Legey LFL, Mazzone A (2013) Energy from sugarcane bagasse in Brazil: An assessment of the productivity and cost of different technological routes. Renew Sustain Energy Rev 21:356-364.

78. Carriquiry MA, Du X, Timilsina GR (2011) Second generation biofuels : Economics and policies. Energy Policy 39:4222-4234.

79. Hamelinck CN, Van Hooijdonk G, Faaij APC (2005) Ethanol from lignocellulosic biomass: Techno-economic

80. Stephen JD (2012) Will second-generation ethanol be able to compete with fi rst-generation ethanol?

81. Tunpaiboon N (2019) Thailand Industry Outlook 2019-21 Ethanol Industry. Krungsri Research.

82. Heinbach K, Aretz A, Hirschl B, Prahl A, Salecki S (2014) Renewable energies and their impact on local value added

83. Chandel AK, da Silva SS, Carvalho, W, Singh OV (2012)Sugarcane bagasse and leaves: foreseeable biomass of biofuel and bio-products. J Chem Technol Biotechnol 87:11-20

84. Ronzon T, M'Barek R (2018) Socioeconomic indicators to monitor the EU's bioeconomy in transition. Sustain 10:1745.

85. Chen H, Fu X (2016) Industrial technologies for bioethanol production from lignocellulosic biomass. Renew Sustain Energy Rev 57:468-478.

86. Kemausuor F, Bolwig S, Miller S (2016) Modelling the socio-economic impacts of modern bioenergy in rural communities in Ghana. Sustain Energy Technol Assessments 14:9-20.

87. Brinkman ML, Wicke B, Faaij APC, Hilst F Van Der (2019) Projecting socio-economic impacts of bioenergy : Current status and limitations of ex-ante quantification methods. 115:109352.

88. Kurka T, Blackwood D (2013) Participatory selection of sustainability criteria and indicators for bioenergy developments. Renew Sustain Energy Rev 24:92-102

9. Hertel TW, Golub AA, Jones AD, O’Hare M, Plevin RJ, Kammen DM (2010) Effects of US Maize ethanol on global 
land use and greenhouse gas emissions: Estimating market-mediated responses. Bioscience 60:223-231.

90. Schmidhuber J, Economist S, Europe N (2006) Impact of an increased biomass use on agricultural markets, prices and food security: A longer-term perspective. 27-29.

91. Hahn-Hägerdal B, Galbe M, Gorwa-Grauslund MF, Lidén G, Zacchi G (2006) Bio-ethanol - the fuel of tomorrow from the residues of today. Trends Biotechnol 24:549-556.

92. Maltsoglou I, Dawe D, Tasciotti L (2010) Bioenergy and Food Security The Household Level Impacts of Increasing Food Prices in Cambodia Household level impacts of increasing food prices. The Bioenergy and Food Security Project, Food and Agriculture Organization of the United Nations. http://www.fao.org/3/i1664e/i1664e.pdf. Accessed 28 Sep 2020.

93. Nualnoom P, Wehrmeyer W, Morse S (2016) Analysing household decision-making on oil palm cultivation in Thailand. J Land Use Sci 11:560-578.

94. Woo H, Moroni M, Park J, Taskhiri MS, Turner P (2020) Residues and bio-energy generation: A case study modelling value chain optimisation in Tasmania. Energy 196:117007.

95. Fahd S, Fiorentino G, Mellino S, Ulgiati S (2012) Cropping bioenergy and biomaterials in marginal land : The added value of the biorefinery concept. Energy 37:79-93.

96. Jiao J, Li J, Bai Y (2019) Uncertainty analysis in the life cycle assessment of cassava ethanol in China. J Clean Prod 206:438-451.

97. Havlı́k P, Schneider UA, Schmid E, Boettcher H, Fritz S, Skalsky R, Aoki K, De Cara S, Kindermann G, Kraxner F, Leduc S, McCallum I, Mosnier A, Sauer T, Obersteiner M (2011) Global land-use implications of first and second generation biofuel targets. Energy Policy 39:5690-5702.

98. Prapaspongsa T, Gheewala SH (2016) Risks of indirect land use impacts and greenhouse gas consequences: an assessment of Thailand's bioethanol policy. J Clean Prod 134:563-573.

99. Hu Z, Fang F, Ben DF, Pu G, Wang C (2004) Net energy, CO2emission, and life-cycle cost assessment of cassavabased ethanol as an alternative automotive fuel in China. Appl Energy 78:247-256.

100. Hanif M, Mahlia TMI, Aditiya HB, Abu Bakar MS (2017) Energy and environmental assessments of bioethanol production from Sri Kanji 1 cassava in Malaysia. Biofuel Res J 4:537-544.

101. Vries SC De, Ven GWJ Van De, Ittersum MK Van (2014) First or second generation biofuel crops in Brandenburg, Germany? A model-based comparison of their production-ecological sustainability. Eur J Agron 52:166-179.

102. Liu B, Wang F, Zhang B, Bi J (2013) Energy balance and GHG emissions of cassava-based fuel ethanol using different planting modes in China. Energy Policy 56:210-220. 
103. Zilberman D, Goetz R, Garrido (Series Eds) (2017) A Natural Resource Management and Policy Handbook of Bioenergy Economics and Policy : Volume II Modeling Land Use and Greenhouse. Springer

104. Morales M, Quintero J, Conejeros R, Aroca G (2015) Life cycle assessment of lignocellulosic bioethanol: Environmental impacts and energy balance. Renew Sustain Energy Rev 42:1349-1361.

105. Whitaker J, Ludley KE, Rowe R, Taylor G, Howard DC (2010) Sources of variability in greenhouse gas and energy balances for biofuel production : a systematic review. GCB Bioenergy 2:99-112.

106. Caldeira-Pires A, Benoist A, Luz SM da, Silverio VC, Silveira CM, Machado FS (2018) Implications of removing straw from soil for bioenergy: An LCA of ethanol production using total sugarcane biomass. J Clean Prod 181:249-259.

107. Ye G, Zeng D, Zhang S, Fan M, Zhang H, Xie J (2018) Ethanol production from mixtures of sugarcane bagasse and Dioscorea composita extracted residue with high solid loading. Bioresour Technol 257:23-29.

108. de Vries SC, van de Ven GWJ, van Ittersum MK, Giller KE (2010) Resource use efficiency and environmental performance of nine major biofuel crops, processed by first-generation conversion techniques. Biomass and Bioenergy 34:588-601.

109. Suramaythangkoor T, Gheewala SH (2011) Implementability of Rice Straw Utilization and Greenhouse Gas Emission Reductions for Heat and Power in Thailand. 133-147.

110. Yu TE, English BC, He L, Larson JA, Calcagno J, Fu JS, Wilson B (2016) Analyzing Economic and Environmental Performance of Switchgrass Biofuel Supply Chains. Bioenergy Res 9:566-577.

111. Wang JJ, Jing YY, Zhang CF, Zhao JH (2009) Review on multi-criteria decision analysis aid in sustainable energy decision-making. Renew Sustain Energy Rev 13:2263-2278.

112. Silalertruksa T, Gheewala SH, Pongpat P (2015) Sustainability assessment of sugarcane biorefinery and molasses ethanol production in Thailand using eco-efficiency indicator. Appl Energy 160:603-609.

113. Pippo WA, Luengo CA, Alonsoamador LL, Alberteris M, Garzone P, Cornacchia G (2011) Energy recovery from sugarcane-trash in the light of 2nd generation biofuel. Part 2: Socio-economic aspects and techno-economic analysis. Waste Biomass Valorizat 2:257-266.

114. Lee HC, Chang C Ter (2018) Comparative analysis of MCDM methods for ranking renewable energy sources in Taiwan. Renew Sustain Energy Rev 92:883-896.

115. Gheewala SH, Damen B, Shi X (2013) Biofuels: Economic, environmental and social benefits and costs for developing countries in Asia. Wiley Interdiscip Rev Clim Chang 4:497-511.

116. Ravindranath NH, Sita Lakshmi C, Manuvie R, Balachandra P (2011) Biofuel production and implications for land use, food production and environment in India. Energy Policy 39:5737-5745. 
117. von Doderer CCC, Kleynhans TE (2014) Determining the most sustainable lignocellulosic bioenergy system following a case study approach. Biomass and Bioenergy 70:273-286.

118. Havlík P, Schneider UA, Schmid E, et al (2011) Global land-use implications of first and second generation biofuel targets. Energy Policy 39:5690-5702.

119. Arodudu O, Helming K, Wiggering H, Voinov A (2017) Towards a more holistic sustainability assessment framework for agro-bioenergy systems - A review. Environ Impact Assess Rev 62:61-75.

120. Arora R, Behera S, Kumar S (2015) Environmental impact of bioethanol production. Renew Sustain Energy Rev 51:699-717.

121. Nguyen TLT, Gheewala SH, Garivait S (2007) Energy balance and GHG-abatement cost of cassava utilization for fuel ethanol in Thailand. Energy Policy 35:4585-4596.

122. Di Zio S, Maretti M (2014) Acceptability of energy sources using an integration of the Delphi method and the analytic hierarchy process. Qual Quant 48:2973-2991.

123. Kheybari S, Rezaie FM, Naji SA, Naja F (2019) Evaluation of energy production technologies from biomass using analytical hierarchy process : The case of Iran. J Cleaner Prod 232:257-265.

124. Ho D, Newell G, Walker A (2005) The importance of property-specific attributes in assessing CBD office building quality. J Prop Invest Financ 23:424-444.

125. Dwivedi P, Alavalapati JRR (2009) Stakeholders' perceptions on forest biomass-based bioenergy development in the southern US. Energy Policy 37:1999-2007.

126. Arof AM (2015) The application of a combined Delphi-AHP method in maritime transport research-A review. Asian Soc Sci 11:73-82.

127. Luzon B, El-Sayegh SM (2016) Evaluating supplier selection criteria for oil and gas projects in the UAE using AHP and Delphi. Int J Constr Manag 16:175-183.

128. Billig E, Thrän D (2016) Evaluation of biomethane technologies in Europe - Technical concepts under the scope of a Delphi-Survey embedded in a multi-criteria analysis. Energy 114:1176-1186.

129. Sawaengsak W, Gheewala SH (2017) Analysis of social and socio-economic impacts of sugarcane production: A case study in Nakhon Ratchasima province of Thailand. J Clean Prod 142:1169-1175.

130. Neamhom T, Polprasert C, Englande AJ (2016) Ways that sugarcane industry can help reduce carbon emissions in Thailand. J Clean Prod 131:561-571.

131. Zhou Z, Jiang H, Qin L (2007) Life cycle sustainability assessment of fuels. Fuel 86:256-263.

132. Budzinski M, Nitzsche R (2016) Comparative economic and environmental assessment of four beech wood based 
biorefinery concepts. Bioresour Technol 216:613-621.

133. Preechajarn S, Prasertsri P, Nicely R (2018) Thailand Biofuels Annual, GAIN Report. Global Agricultural Information Network. USDA Foreign Agricultrual Service. https://apps.fas.usda.gov/newgainapi/api/report/downloadreportbyfilename?filename=Biofuels\%20Annual_Bang kok Thailand 12-19-2018.pdf. Accessed 18 November 2020

134. Littlewood J, Murphy RJ, Wang L (2013) Importance of policy support and feedstock prices on economic feasibility of bioethanol production from wheat straw in the UK. Renew Sustain Energy Rev 17:291-300.

135. World Bank Group WB (2020) State and Trends of Carbon Pricing 2020. http://hdl.handle.net/10986/33809. Accessed 9 November 2020.

136. Timilsina GR, Csordás S, Mevel S (2011) When does a carbon tax on fossil fuels stimulate biofuels? Ecol Econ 70:2400-2415.

137. The Office of Natural Resources and Environmental Policy and Planning, Ministry of Natural Resources and Environment (2016) Climate Change Master Plan 2015-2050. https://climate.onep.go.th/wpcontent/uploads/2019/07/CCMP_english.pdf. Accessed 5 November 2020.

138. International Energy Agency (2020) Putting a price on carbon - an efficient way for Thailand to meet its bold emission target. https://www.iea.org/articles/putting-a-price-on-carbon-an-efficient-way-for-thailand-to-meet-itsbold-emission-target. Accessed 5 November 2020.

139. Phungrassami H, Usubharatana P (2019) Fossil fuel carbon taxation policy effect on thai household expenditure using input-output price structural path model. Environ Prog Sustain Energy 38:5. https://doi.org/10.1002/ep.13183.

140. Wattanakuljarus A (2019) Effects and burdens of a carbon tax scheme in Thailand. Eurasian Econ Rev 9:173-219.

141. Garivait S, Chaiyo U, Patumsawad S, Deakhuntod J (2013) Fuel Characteristics of Agricultural Residues in Thailand. Energy Sources 35:826-830.

142. Tun MM, Juchelkova D, Win MM, Thu AM, Puchor T (2019) Biomass Energy : An Overview of Biomass Sources, Energy Potential , and Management in Southeast Asian Countries. Resources 8:81.

143. Lecksiwilai N, Gheewala SH, Sagisaka M, Yamaguchi K (2016) Net Energy Ratio and Life cycle greenhouse gases (GHG) assessment of bio-dimethyl ether (DME) produced from various agricultural residues in Thailand. J Clean Prod 134:523-531.

144. Phumee P, Pagdee A, Kawasaki J (2018) Energy crops, livelihoods, and legal deforestation: A case study at Phu Wiang National Park, Thailand. J Sustain For 37:120-138. 
1 145. Thai Laws (1964) National Reserved Forest Act, B.E. 2507. www.thailaws.com. Accessed 25 November 2020.

2 146. Phairuang W, Hata M, Furuuchi M (2017) Influence of agricultural activities, forest fires and agro-industries on air quality in Thailand. J Environ Sci (China) 52:85-97.

4 147. Chaya W, Jesdapipat S, Tripetchkul S, Santitaweeroek Y, Gheewala SH (2019) Challenges and pitfalls in implementing Thailand's ethanol plan: Integrated policy coherence and gap analysis. Energy Policy 132:1050-1063.

148. Kurka T, Jefferies C, Blackwood D (2012) GIS-based location suitability of decentralized, medium scale bioenergy developments to estimate transport CO 2 emissions and costs. Biomass and Bioenergy 46:366-379.

149. Palmas C, Abis E, von Haaren C, Lovett A (2012) Renewables in residential development: An integrated GIS-based multicriteria approach for decentralized micro-renewable energy production in new settlement development: $\mathrm{A}$ case study of the eastern metropolitan area of Cagliari, Sardinia, Italy. Energy Sustain Soc 2:1-15.

150. Yoshida K, Srisutham M, Sritumboon S, Suanburi D, Janjirauttikul N (2019) Weather - induced economic damage to upland crops and the impact on farmer household income in Northeast Thailand. Paddy Water Environ 17:341-349.

151. Kumar S, Abdul Salam P, Shrestha P, Ackom EK (2013) An assessment of thailand's biofuel development. Sustain $5: 1577-1597$.

152. Zhang Y, Goldberg M, Tan E, Meyer PA (2012) Estimation of economic impacts of cellulosic biofuel production: a comparative analysis of three biofuel pathways. Biofuels, Bioprod Biorefining 6:246-256.

153. Dias MOS, Junqueira TL, Cavalett O, Pavanello LG, Cunha MP, Jesus CDF, Maciel Filho R, Bonomi A (2013) 109:72-78. 
Figures



Figure 1

process flow of the current study 


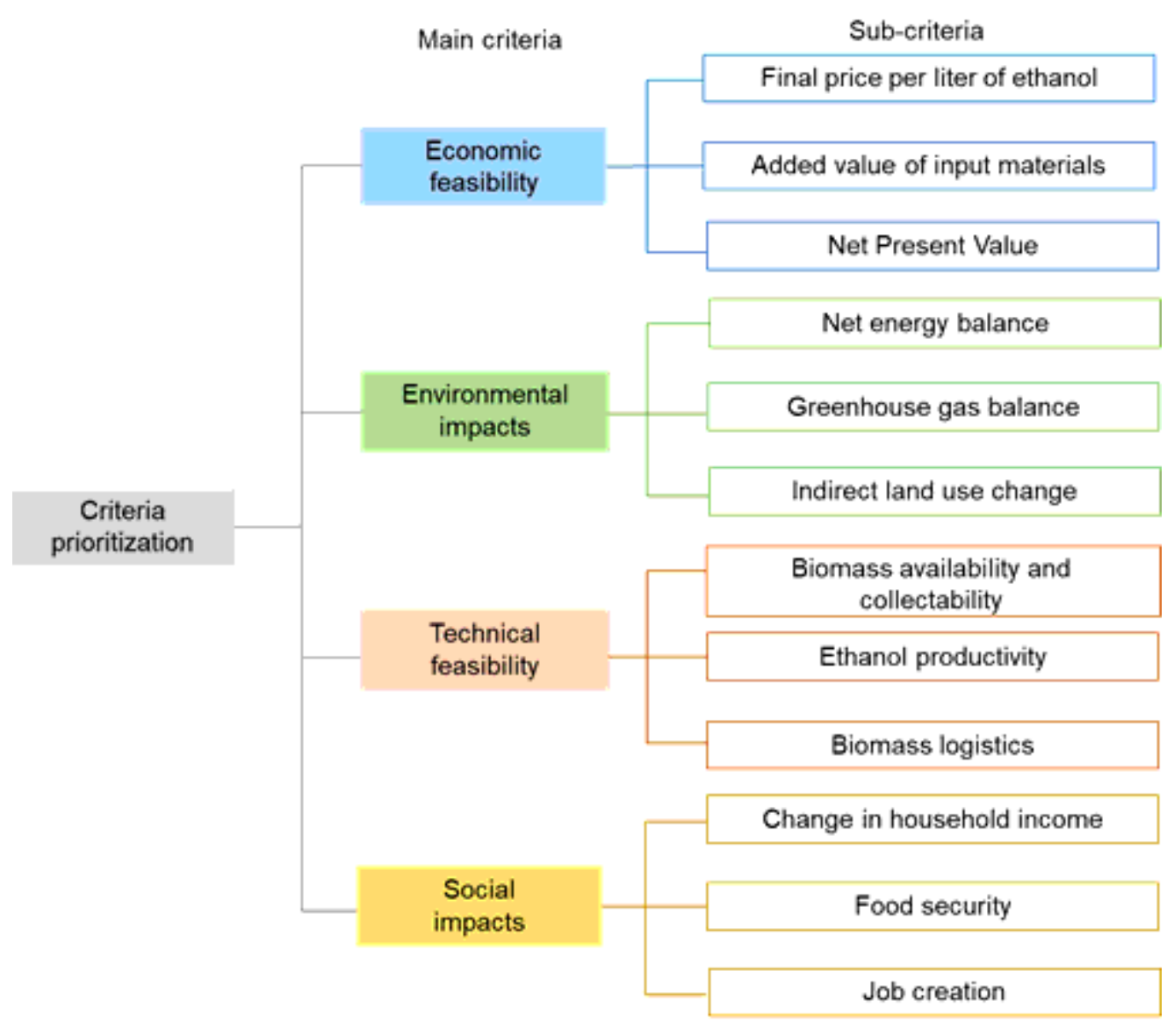

Figure 2

Hierarchical structure of selected main criteria and sub-criteria

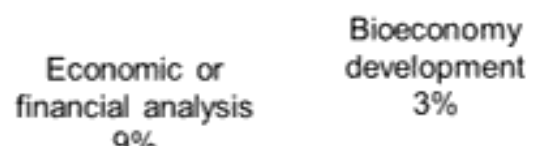

$9 \%$

Business analysis or investment $6 \%$

\section{Socio-economic impacts analysis $6 \%$}

\section{Environmental impacts analysis $9 \%$}

Technology development or project development $8 \%$
Energy policy $17 \%$

\section{Agricultural production $17 \%$}

$$
\begin{array}{cc}
\begin{array}{c}
\text { Renewable energy } \\
\text { development or }
\end{array} & \begin{array}{c}
\text { Bioethanol or biofuel } \\
\text { production }
\end{array} \\
\text { energy management } & 14 \% \\
3 \% &
\end{array}
$$ production $14 \%$

Biomass

management or biomass conversion $8 \%$ 
Figure 3

Proportions of areas of expertise in a group of participants

Academic/Research

$35.2 \%$

$25.1 \%$

$19.9 \%$

$19.9 \%$

NPO/NGO

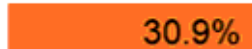

$28.9 \%$

$13.0 \%$

$27.2 \%$

Industry / Business sectors

$20.8 \%$

$30.9 \%$

$17.8 \%$

$30.5 \%$

Government/ Ministry/ Policy makers

\section{$13.6 \%$}

$33.2 \%$

$23.0 \%$

$30.1 \%$

Financial institution/ Bank

$$
19.3 \%
$$

$43.6 \%$

Overall relative weight



32.3

18.1

25.6

$0 \%$

$20 \%$

$40 \%$

$60 \%$

$80 \%$

$100 \%$

- Technical feasibility

Economic Feasibility $\square$ Social impacts

Environmental impacts

\section{Figure 4}

Main criteria prioritization divided by types of organizations and overall scores from all participants 


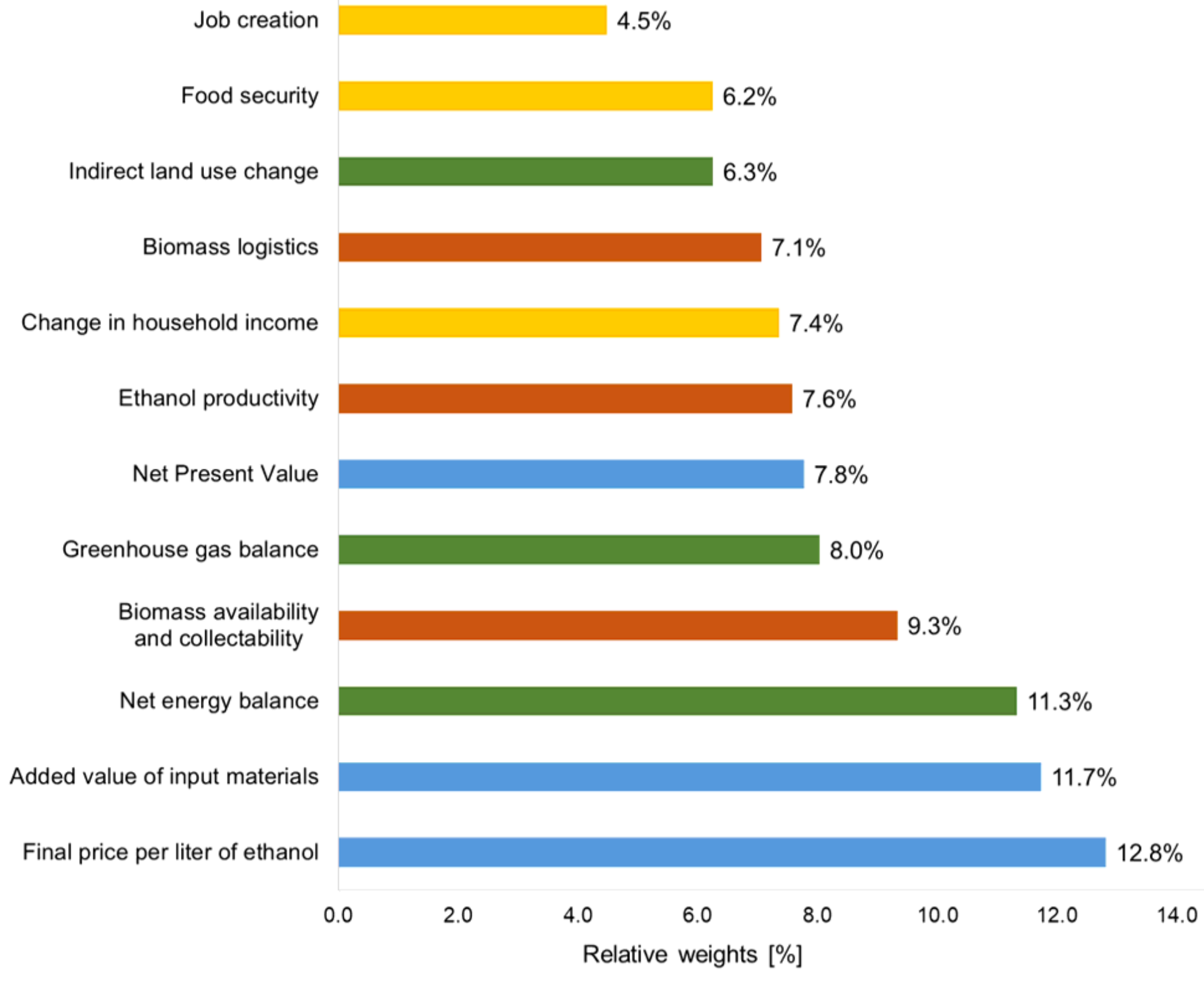

\section{Figure 5}

Range of relative weights in each sub-criteria 


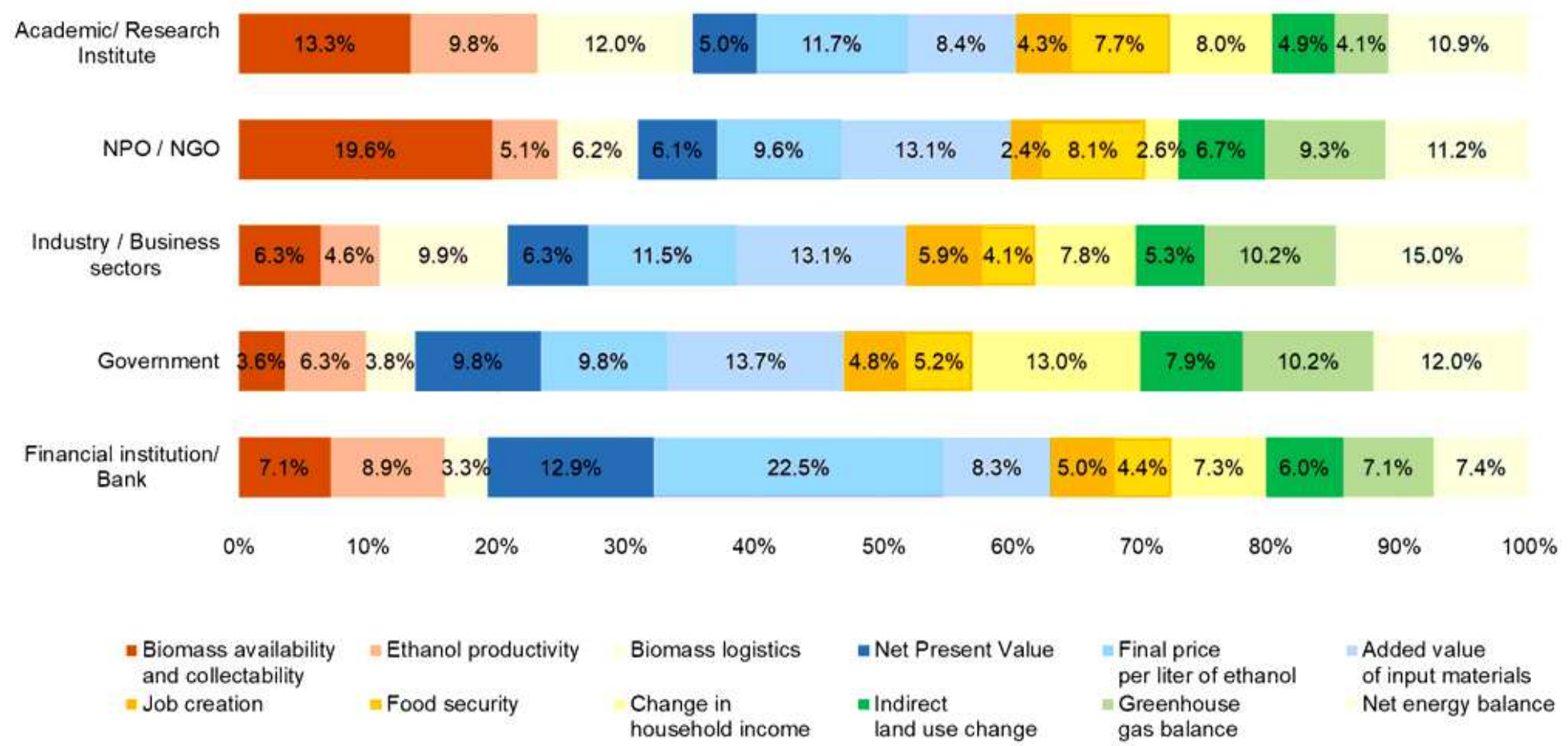

\section{Figure 6}

Relative weights for each sub-criteria as categorized by stakeholders in this study



\section{Figure 7}


Sankey diagram for illustrating the relationship between the categories "Field of expertise", "Type of organization" and "Criteria weights" as derived from the Delphi-AHP results

\section{Supplementary Files}

This is a list of supplementary files associated with this preprint. Click to download.

- SupplementarymaterialPiradeeJusakulvijit.pdf

- Table1.xlsx

- Table2.xlsx

- Table3.xlsx

- Table4.xlsx

- Table5.xlsx

- Table6.xlsx

- Table7.xlsx 